\title{
PSYCHROPHILIC AND PSYCHROTOLERANT MICROBIAL EXTREMOPHILES IN
} POLAR ENVIRONMENTS

\author{
Richard B. Hoover ${ }^{\mathrm{a}}$ and Elena V. Pikuta ${ }^{\mathrm{b}}$ \\ ${ }^{a}$ Space Science Office, Mail Code 62, NASA/Marshall Space Flight Center, Huntsville, AL 35812 \\ ${ }^{\mathrm{b}}$ National Space Science and Technology Center, 320 Sparkman Dr., Huntsville, AL 35805, USA \\ Richard.Hoover@NASA.GOV
}

\section{CONTENTS}

\section{INTRODUCTION}

2. PRODUCERS OF ORGANIC MATTER IN POLAR ENVIRONMENTS

2.1 Eukaryotic Photosynthetic Microorganisms.

2.1.1 Diatoms

2.1.2 Snow Algae

2.1.3 Prokaryotic Photosynthetic Microorganisms

2.1.4 Bioremediation by Diatoms and Cyanobacteria

2.2. Psychrophilic and Psychrotolerant Anaerobic Chemolithotrophic Autotrophs

2.2.1 Methanogens

2.2.2 Acetogens

\section{DECOMPOSERS OF ORGANIC MATTER IN POLAR ENVIRONMENTS}

\section{EXTREMOPHILES WITHIN PHYSICO-CHEMICAL MATRIX}

5. ANAEROBIC EXTREMOPHILES FROM POLAR EXPEDITIONS

5.1 Novel Psychrotolerant Extremophiles from Expeditions to Alaska

5.1.1 Pleistocene Bacterium from Fox Permafrost Tunnel

5.1.2 Novel Acidophile from Chena Hot Springs

5.2 Novel Extremophiles from Antarctica 2000 Expedition

5.2.1 Psychrotolerant Anaerobes from Magellanic Penguin Colony in Southern Patagonia, Chile

5.2.2 Novel Psychrophilic and Psychrotolerant Anaerobes from Patriot Hills, Antarctica

5.32008 Tawani International Antarctica Expeditions

5.3.1 Psychrotolerant Anaerobes from the African Penguin guano

5.3.2 Microbial Extremophiles from the Schirmacher Oasis, Antarctica

5.3.2.1 Bacteria from Lake Zub (Lake Priyadarshini)

5.3.2.2 Bacteria from Ice Sculptures near Lake Podprudnoye

5.4 Microbial Extremophiles from Lake Untersee

5.4.1 Psychrophilic and Psychrotolerant Anaerobes from Lake Untersee

5.5 Microorganisms in-situ in Ice-Bubbles

6.0 RELEVANCE OF POLAR MICROBIAL EXTREMOPHILES TO ASTROBIOLOGY

7.0 SUMMARY

8.0 REFERENCES

Acknowledgements 


\section{INTRODUCTION}

Microbial extremophiles are the dominant life forms of the polar environments. They are able to survive in the extreme polar environments and have developed mechanisms that allow them to cope with a variety of stressors. These include freezing temperatures and repeated freeze-thaw cycles, desiccation, high or low levels of salinity or $\mathrm{pH}$, and lengthy periods of darkness during winter. Polar life forms must also be able to survive exposure to high levels of solar UVB (280-314 nm) radiation due to stratospheric ozone depletion over the Antarctic (McKenzie et al. 2003) and Arctic regions during the summer (Knudsen et al. 2005). The dominant prokaryotes of polar environments are psychrophilic and psychrotolerant bacteria and archaea and the dominant photosynthetic eukaryotes are algae, primarily diatoms.

Morita (1975) defined psychrophiles as organisms that have optimal temperature for growth below 15 ${ }^{\circ} \mathrm{C}$ and maximal temperature for growth at $20{ }^{\circ} \mathrm{C}$. Psychrotolerant organisms are able to grow at low temperatures with much lower rates, and they have growth optima in the range of mesophilic organisms $\left(20-40{ }^{\circ} \mathrm{C}\right)$. Psychrotolerant microorganisms are usually the organisms most frequently found in cold environments, perhaps because they may have better nutritional adaptability (Wynn-Williams 1990) or due to horizontal gene transfer from mesophiles (Aislabie et al., 2004). Many of these are psychrotolerant bacteria found in mesophilic environments and may have been transferred to Antarctica.

It has been known since 1887 that some species of bacteria were capable of growth at $0{ }^{\circ} \mathrm{C}$ or below (Foster, 1887). In 1918, McClean reported the isolation of gram positive cocci and gram negative spore-forming and non-spore forming rods from the snow, ice, and frozen algae of Antarctica. Darling and Siple (1941) isolated 178 strains from the snow, ice, soil and debris of Antarctica. Strada and Stokes (1960) reported psychrophilic bacteria from ice and guano in Antarctica, but due to a difference in terminology the growth characteristics indicate that many of these bacteria were actually psychrotolerant rather than true psychrophiles. However, most of the knowledge about psychrophilic and psychrotolerant microorganisms and their habitats has been gained in the past three decades. Extensive studies of microbial life in the polar environments have been carried out and new taxa of psychrophiles have been discovered and described (Reddy et al., 2003, Mountfort et al., 1997).

Now, there is much better understanding of the mechanisms for survival in polar environments. Survival strategies include genetic and acclimation processes and adaptations (Vincent, 2000; Elster, 1999, 2002). These include mechanisms such as seasonally induced dormancy, production of pigments, exopolysaccharides and sheaths to protect from UV radiation and the utilization of specialized enzymes and cryoprotectants to prevent cell lysis during freeze-thaw cycles.

Concerning metabolism, among psychrophiles, the organo-hetherotrophic and phototrophic types are predominant. The lithoautotrophic type, which is the earliest by the evolutionary scale, and usually is characteristic for hyperthermophiles, is common only for some species of psychrotolerant methanogenic archaea, bacterial methanotrophs and homoacetogens inhabiting polar peat bogs (Zhang et al., 2008; Dedysh et al., 2000; Trotsenko \& Khmelenina, 2005). Reports about lithotrophic, psychrophilic, sulfate-reducing bacteria have also been published (Geittel et al., 2008).

Modern biotechnology requires polymeric molecules, which function at extreme physico-chemical parameters. Psychrophilic and psychrotolerant microorganisms and their unique cold shock and cold- 
acclimation proteins and enzymes (e.g., proteases, lipases and cellulases) have a host of biotechnology applications (Gounot, 1991). These include cold-water detergents, food additives and flavor modifying agents, biosensors, and environmental bioremediation. The exclusively temperature-sensitive molecules and enzymes of psychrophiles have applications in pharmaceuticals. The cryoprotectors synthesized by psychrophilic and psychrotolerant microorganisms are used in cosmetics, medicine, and agriculture.

A detailed review of the biotechnology applications of psychrophilic and psychrotolerant microorganisms has been presented by Huston (2007). Psychrotolerant microorganisms are great value for bioremediation of hydrocarbon-contaminated soil in Antarctica in that they have the ability to maintain activity under the extreme conditions of the polar environment (Bej et al. 2000; Paniker et al. 2000, 2006). Several new strains of psychrotolerant bacteria have been isolated from oil-contaminated soil in Antarctica and studied in detail (Aislabie et al., 2000; Bej et al., 2000). Horizontal gene transfer mechanisms have been shown for cold-adapted aromatic degrading bacteria (Aislabie et al., 2004, 2006). Molecular methods help to understand the distribution of microorganisms in polar environments (natural and contaminated ecosystems). Gene mapping has been performed for several ecosystems and demonstrated the wide microbial diversity in these environments. (Jucke et al., 2000).

Investigations of microbial extremophiles in polar environments are important to understanding environmental change, global warming, and the newly emerging field of Astrobiology. Using three decades of satellite (Coastal Color Scanner and Sea-Viewing Wide Field-of-View Sensor) and field observations Montes-Hugo et al. (2009) showed that ocean zone biological productivity, estimated by the measurements of surface chlorophyll $a$ concentrations along the West Antarctic Peninsula, has declined by $12 \%$. Large scale climate changes could alter the content of microbial communities, especially in Polar Regions, possibly contributing to the natural process of substitution of true psychrophilic species by psychrotolerant ones, accompanied by gene-transfer and other processes.

A key element of Astrobiology is the study of the limits and diversity of microbial life in the most extreme environments on Earth. Since water is crucial for life as we know it, the most important Astrobiology targets are the frozen worlds of the Solar System bodies where water is present either in liquid or solid state. These include comets or water bearing asteroids; the permafrost, craters, or Polar Ice Caps of Mars; and the icy moons of Jupiter (e.g., Europa, Callisto, Io, or Ganymede) or Saturn (e.g., Titan or Enceladus). The polar environments of Earth provide the best terrestrial analogues for these regimes. Consequently, the nature and distribution of microbial extremophiles that inhabit the Earth's Polar Regions may provide valuable information crucial to the development of instruments and operational techniques needed to search for and to recognize evidence of extant or extinct life elsewhere in the Cosmos.

In this chapter we review recent information about psychrophilic and psychrotolerant microorganisms isolated from different cold environments. We provide some preliminary data on the isolation, morphology and physiology of novel anaerobic microbial extremophiles from polar environments (and psychrotolerant strains isolated from penguin guano) in the logic scheme for biogeochemical cycling of organic matter divided into two major groups 1) the producers and 2) the decomposers of organic matter. This arrangement does not cover an exact functional meaning for all reviewed microorganisms, since it is difficult to put the metabolic diversity of organisms under one universal definition. For example, some phototrophs can use the photo-heterotrophic and, even, organo-heterotrophic pathways in metabolism, depending upon conditions. There are species of diatoms and green algae that lack pigments and support their life cycle exclusively by organohetherotrophic metabolism. Furthermore, some anaerobic decomposers, which are lithohetherotrophs or organotrophs, are also able to synthesize 
organic matter from inorganic compounds; for example, some methanogenic archaea and bacterial homoacetogens are able to use lithoautotrophic metabolic pathways.

\section{PRODUCERS OF ORGANIC MATTER IN POLAR ENVIRONMENTS}

In the polar environments, the dominant primary producers of organic matter are the photosynthetic eukyarotic algae (mainly diatoms and snow algae) and photosynthetic prokaryotes (mainly cyanobacteria). The chemolithoautrophic producers of organic matter in anaerobic communities of polar regions are limited to the methanogenic archaea and homoacetogenic bacteria that are able to grow on hydrogen and $\mathrm{CO}_{2} / \mathrm{CO}$ or just on $\mathrm{CO}_{2}$ (Simankova et al. 2000).

\subsection{Eukaryotic Photosynthetic Microorganisms.}

\subsubsection{Diatoms}

Psychrophilic and psychrotolerant diatoms are the most abundant unicellular eukaryotes of the polar environments. Diatoms have also been extensively studied in the polar oceans, sea ice, high alpine regions and the freshwater lakes, streams and soils of Antarctica. These photoautotrophic microalgae are one of the most important groups of the phytoplankton of the polar oceans. Diatoms are responsible for most of the primary productivity in the polar oceans and they are the principal component of the entire polar food chain - feeding the krill, fish, whales, penguins and other sea birds. One of the main habitats of polar diatoms is sea ice. Diatoms are so abundant in the polar oceans that they produce vast "blooms" during the polar spring that can best be appreciated from satellite imagery. This is due to the presence of high silica concentrations in the polar oceans coupled with the remarkably successful adaptations of diatoms to the polar environment.

Early investigations of polar marine diatoms were carried out by Castracane (1886) during the 18731876 HMS Challenger Expedition and by Henri van Heurck during the 1897-1899 voyage of the S. Y. Belgica (van Heurck, 1909). Freshwater diatoms from the South Georgia Island were described by Reinsch (1890). The dominant diatoms of the polar oceans include many marine centrics, such as Chaetoceras criophilum, Asteromphalus spp. Actinocyclus karstenii, A. curvatulus, Azpeitia tabularis, Coscinodiscus spp., Corethron criophilum, Thalassiosira Antarctica, T. pseudonana as well as pennates such as Fragilariopsis kerguelensis. The pack-ice and sea-ice communities are dominated by small pennates, such as Fragilariopsis curta, Fragilariopsis cylindrus, Amphiprora spp., Navicula spp., and Nitzschia spp. Diatoms have been studied from the Antarctic ice-cores (Burkle et al. 1988). Diatom frustules (and in some cases intact cells) have been found in some of the very deep ice cores above Lake Vostok (Abyzov et al. 2006). Freshwater diatoms have been used as indicators of environmental change in the high arctic (Douglas and Smol, 1999) and for monitoring human induced environmental changes in tundra ecosystems (Smol and Douglas, 1996). While an exhaustive description of the modern work on polar diatoms is beyond the scope of this article, the reader is referred to Kellogg and Kellogg (2002) for an updated taxonomy of the non-marine diatoms from the Antarctic and Subantarctic regions. Reviews of psychrophilic diatoms and their mechanisms for survival in cold environments have more recently been given by Spaulding and McKnight (1999) and Mock and Junge (2007). 


\subsubsection{Snow Algae}

Several species of eukaryotic microalgae have adapted to growth at low temperature and thrive in melting snow and can color the snow pink, red, green, or yellow (Hoham, 1975). Chlamydomonas nivalis is the most common species of the snow algae. Other algae that grow on snow include species of the genera Ankistrodesmis, Chloromonas and Raphidonema. Chlamydomonas nivalis is a green alga that grows actively as the snow melts during the spring and summer and sunlight penetrates the snow pack. Although the vegetative cells of Chlamydomonas nivalis are green, it has bright red spores. Their presence in large numbers produces large expanses of red "watermelon snow". The complex life cycle of the snow algae in which the vegetative cells, sexual stage and spores alternate have been described by Hoham and Ling (2000). Figure 1.a. shows a snow bank in the Kolyma Lowlands of North Siberia with red patches produced by the spores (Fig. 1.b) of Chlamydomonas nivalis. Experiments for the determination of UV tolerance have showed that among the eukaryotic phototrophs the green snow algae Chlamydomonas nivalis was resistant to high levels of UV radiation (UV-A, $365 \mathrm{~nm}$, and UV-C, $254 \mathrm{~nm}$ ) by the production of flavonoids as an antioxidant and by the accumulation of astaxanthin esterified with fatty acids (Duval et al., 2000; Hoham and Ling, 2000).

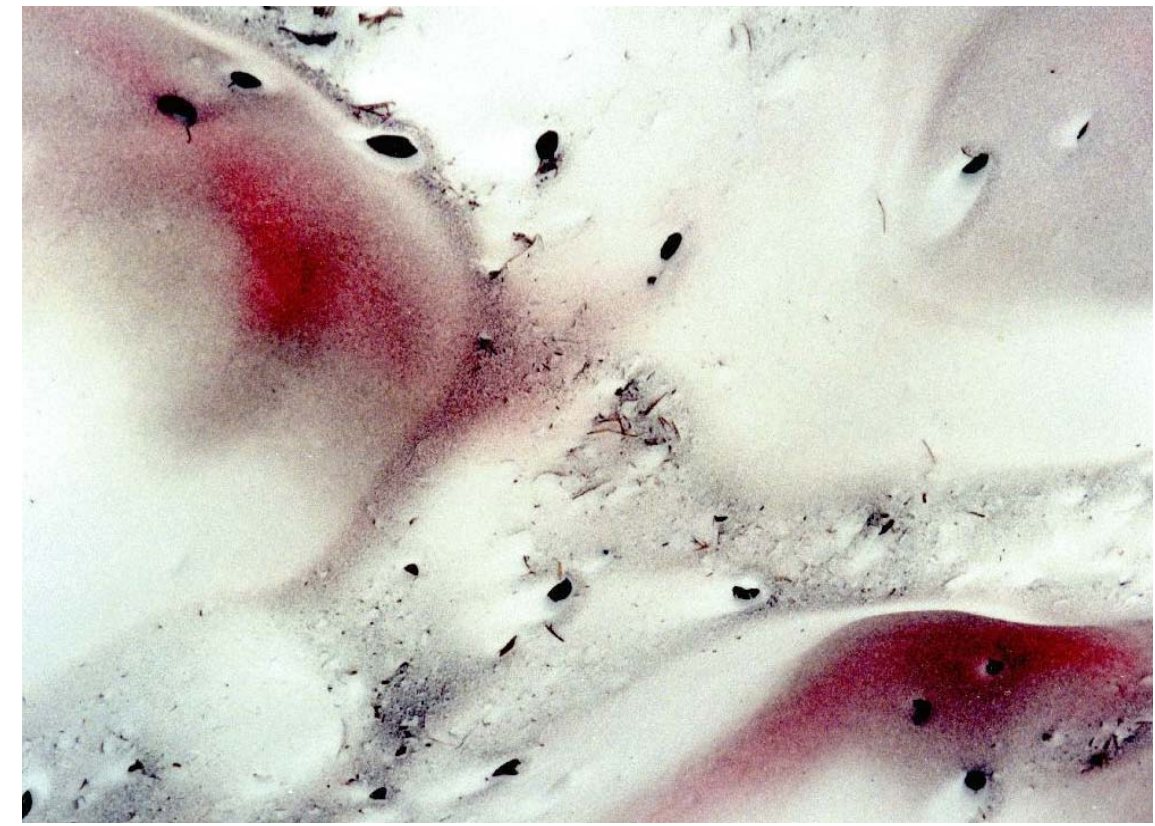

a.

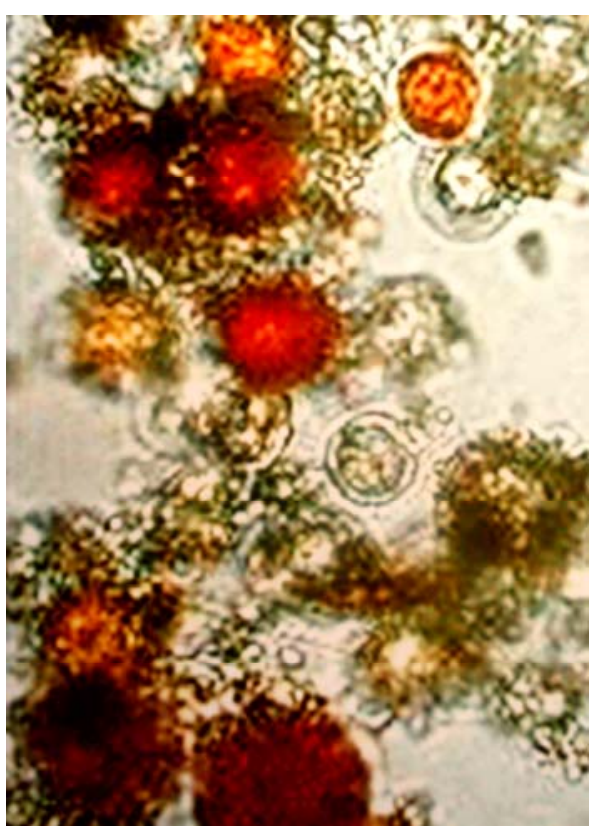

b.

Fig. 1.a. Chlamydomonas nivalis on a snow bank in the Kolyma Lowlands, North Siberia and b. Photomicrograph of red spores of $C$. nivalis.

\subsubsection{Prokaryotic Photosynthetic Microorganisms}

Cyanobacteria are the dominant photosynthetic prokaryotes of the polar regions. While they are rare or absent in the marine environment of the Arctic and the Antarctic, they are found in all freshwater environments of Antarctica (Seckbach \& Oren 2007). Oscillatorian cyanobacteria are the dominant forms in the benthic mats of polar freshwater ecosystems. The cyanobacteria of the polar regions often contain high levels of canthaxanthin, myxoxanthophyll, and other carotenoids with the ratio carotenoids/chlorophyll $a$ being maximal under low temperatures, high light regimes, and moderate UV radiation (Vincent, 2000). All of the species of cyanobacteria that have been isolated from the Polar 
Regions are psychrotolerant rather than truly psychrophilic (Nadeau \& Castenholz, 2000). And contversely, the polar eukaryotic algae, especially the diatoms and the green algae, that grow at subzero temperatures, are psychrophiles.

\subsubsection{Bioremediation by Diatoms and Cyanobacteria}

Although diatoms and cyanobacteria are the major phototrophic eukaryotic microorganisms in the polar environments they have not yet found extensive applications in bio-remediation. Some species of planktonic and benthic diatoms concentrate heavy metals and radio-isotopes by non-specific bioaccumulation, etc. (Absil and van Scheppingen, 1996). Adam and Garnier-Laplace (2003) carried out laboratory experiments to assess the uptake of several radio-isotopes $\left({ }^{110} \mathrm{Ag},{ }^{60} \mathrm{Co},{ }^{137} \mathrm{Cs}\right.$, and $\left.{ }^{54} \mathrm{Mn}\right)$ by the diatom Cyclotella meneghiana and the chlorophyte Scenedesmus obliquus. Some species of diatoms and oscillatorian cyanobacteria have been shown to be able to partially oxidize hydrocarbons such as naphthalene, biphenyl when grown phototrophically (Cerniglia et al, 1980). Phenanthrene is widely distributed in the environment and it is widely used as a model for carcinogenic polycyclic aromatic hydrocarbons (Bücker et al., 1979). Narro et al. (1992) reported that the marine cyanobacterium Agmenellum quadruplicatum PR-6 could oxidize and metabolize the tri-cyclic aromatic hydrocarbon phenanthrene. Cavanagh et al. (1998) isolated marine bacteria from sands of the Vestfold Hills, East Antarctica that were able to degrade phenanthrene. The diatom Achnanthes minitussima and the cyanobacterium Phormidium foveolarum was capable of degradation of naphthenic hydrocarbons (Antić et al. 2006). The marine diatom Skeletonema costatum has been found to have selected detoxification and enzymatic response to 2,4-dichlorophenol (2,4-DCP). The 2,4-DCP was readily metabolized, but the bioaccumulation and adsorption was negligible (Yang et al., 2002). Cold-adapted planktonic and benthic diatoms and other microalgae may find important applications in bioremediation strategies for the bioaccumulation and removal of some recalcitrant hydrocarbons, heavy metals and radio-isotopes from polar environments.

\subsection{Psychrophilic and Psychrotolerant Anaerobic Chemolithotrophic Autotrophs}

\subsubsection{Methanogens}

Psychrotolerant methanogens from polar peat bogs have been known for a relatively long time. In the last fifteen years many true psychrophilic species of methanogenic archaea were reported. The most studied species, Methanogenium frigidum, was isolated from an anaerobic water sample at the hypolimnion level in the perennially cold Ace Lake, in Vestfold Hills, Antarctica (Franzmann et al. 1997). It is the first described psychrophilic methanogen with lithoautotrophic metabolism: the best growth was observed on $\mathrm{H}_{2}+\mathrm{CO}_{2}$. However, the addition of yeast extract significantly stimulated growth. The cells tolerated $10 \%$ salinity and were neutrophilic. This species grew optimally at $15{ }^{\circ} \mathrm{C}$ and did not grow at 18-20 ${ }^{\circ} \mathrm{C}$. Another psychrophile, "Methanolobus psychrophilus", was been described but is not yet validated. It also had optimum of growth at $15{ }^{\circ} \mathrm{C}$ (Zhang et al., 2008). This study indicates that psychrophilic methanogenesis in the Zoige wetland is more likely to be methylotrophic, rather than hydrogenotrophic, and plays a significant role in the methane emission of the wetlands. Since methane is a very important greenhouse gas, this research is also relevant to global warming studies.

The psychrotolerant methanogen, Methanosarcina lacustris, was isolated from anoxic lake sediments in Switzerland (Simankova et al., 2004). The organism utilized methanol, mono-, di-, trimethylamine and $\mathrm{H}_{2} / \mathrm{CO}_{2}$ with methane production, and grew at $1-35{ }^{\circ} \mathrm{C}$ with an optimum at $25{ }^{\circ} \mathrm{C}$. Another 
psychrotolerant methanogen Methanogenium marinum AK-1 grows at $5-25{ }^{\circ} \mathrm{C}$ and was isolated from cold marine sediments at Skan Bay, Alaska (Chong et al., 2002). The cells of this species grow on $\mathrm{H}_{2}+\mathrm{CO}_{2}$ or formate $+\mathrm{CO}_{2}$ at $\mathrm{pH}$ 6.0-6.6 and salinity $0.25-1.25 \mathrm{M}$.

The isolation of methanogens in enrichment culture from acidic peat bog was reported (Bräuer et al., 2006). Another work (Nozhevnikova et al., 2004) proved the existence of psychrophilic methanogenic communities in sediments of deep lakes with low-temperatures $\left(4\right.$ to $\left.5^{\circ} \mathrm{C}\right)$. It was shown that hydrogenamended cultures had the highest methane production rates at $6^{\circ} \mathrm{C}$. Investigations of methanogens for polar environments are also of great interest to Astrobiology. Morozova et al., (2006) carried out experiments that demonstrated the survival of methanogenic archaea from Siberian permafrost under simulated Martian thermal conditions.

The study of biodiversity of methanogenic and other Archaea in the permanently frozen Lake Fryxell in Antarctica has also been performed (Karr et al., 2006). The phylogenetic analysis of the 16S rRNA gene sequences obtained showed that at least four clusters of Archaea inhabited Lake Fryxell - three clusters of Euryarchaeota and one of Crenarchaeota. Within the Euryarchaeota, at least two clusters of methanogens were detected. Some phylotypes were closely related to $16 \mathrm{~S}$ rRNA gene sequences from Methanosarcina species. The presence of Methanosarcina-like methanogens in Lake Fryxell sediments has been confirmed by the isolation of strain FRX-1, a methylotrophic Methanosarcina species growing at $5{ }^{\circ} \mathrm{C}$ (Singh et al., 2005). The other phylotypes of methanogens in Lake Fryxell sediments clustered with species of Methanoculleus. Unlike Methanosarcina, no cultures of Methanoculleus species have been obtained from Lake Fryxell; however, a Methanoculleus-like 16S rRNA gene was previously detected in a molecular diversity study of the cyanobacterial mats that develop in the peripheral melt waters of this lake (Brambilla et al., 2001; Taton et al., 2003).

\subsubsection{Acetogens}

The first report of a psychrophilic homoacetogenic bacteria was Acetobacterium carbinolicum strain HP4, which was isolated by Bak in 1988 (Conrad et al., 1989). As it was shown later that strain HP4 was phylogenetically identified as Acetobacterium carbinolicum, the species that was previously described by Eichler \& Schink (1984). This strain had growth range of $1-25^{\circ} \mathrm{C}$

Chronologically, the next three homoacetogenic isolates were described as the new psychrophilic species A. bakii, A. paludosum and A. fimetarium (Kotsyurbenko et al., 1995). Another psychrotolerant homoacetogen A. tundrae was isolated from the tundra wetland soil sample collected in Polar Ural (Simankova et al., 2000). However, all of these species were able to grow at 30 or $35^{\circ} \mathrm{C}$ with optimal growth at $20-30{ }^{\circ} \mathrm{C}$, indicating they are psychrotiolerant microorganisms rather than true psychrophiles.

New subspecies kysingense of the species A. carbinolicum strain SyrA5 was isolated from anaerobic sediments of brackish fjord (Paarup et al., 2005). This isolate was also psychrotolerant and able to grow lithotrophically on $\mathrm{H}_{2}+\mathrm{CO}_{2}$ and on $\mathrm{CO}$.

Two strains of acetogenic bacteria LS1 and LS2 were isolated from surficial sediments of the permanently ice-covered, meromictic Lake Fryxell in McMurdo Dry Valleys, Antarctica (Sattley \& Madigan, 2007). It was shown that these isolates represent the first acetogens able to grow at subzero temperatures, but their range of growth $-2.5{ }^{\circ} \mathrm{C}$ to $25{ }^{\circ} \mathrm{C}$ exceeds the upper limit $\left(20{ }^{\circ} \mathrm{C}\right)$ for psychrophiles in accordance with the definition provided by Morita (1975). 
The homo-acetogenic bacteria are competing with methanogens and sulfate-reducing bacteria for hydrogen and other inorganic and organic substrates within oligotrophic polar environments. It was shown that at low temperatures homoacetogenic bacteria had significantly predominant activity, compare to methanogens and sulfate-reducing bacteria (Simankova et al., 2000; Kotsyrbenko et al., 2001; Nozhevnikova et al., 2001).

Gaidos et al., (2008) studied the microbial diversity of one of Iceland's volcanic subglacial lakes and they made an unsuccessful attempt to isolate a new psychrophilic acetogenic strain found there, the phylotype of which belongs to the genus Acetobacterium.

Here, we are reporting two strains (str. A7AC-96m and str. A7AC-DS7) of truly psychrophilic homoacetogenic bacteria that were isolated from water and sediment samples collected from the $96 \mathrm{~m}$ region of the deep anoxic trough of Lake Untersee in Antarctica. Both of these strains have maximum temperature for growth at $14{ }^{\circ} \mathrm{C}$ and are able to grow on $\mathrm{H}_{2}+\mathrm{CO}_{2}$.

\section{DECOMPOSERS OF ORGANIC MATTER IN POLAR ENVIRONMENTS}

All microorganisms that participate in the process of decomposition of organic matter in polar environments are chemo-organotrophs. Some of the best studied systems of decomposers of organic matter in polar environments are of the psychrophilic and psychrotolerant microorganisms that inhabit the peat bogs and permafrost soils of Alaska, Canada, North-Eastern Europe, Patagonia, and Siberia. Many species of bacteria and Archaea were described and characterized. It is noted that the haloalkaline lakes on Earth have not previously been investigated for psychrophiles. All reported studies of the halo-alkaline lakes in Siberia (Russia) and Canada were limited exclusively to mesophilic microorganisms. Perhaps this was because of lack of specific equipment and techniques for the isolation of true psychrophiles, or specific conditions for the storage or transport of samples (extreme sensitivity of psychrophilic microorganisms to warm temperatures).

During the past decade from cold deep sea samples many new marine psychrophiles, representing several separate new genera and species, have been isolated and described (Mountfort et al., 1998; Romanenko et al., 2002; Bowman et al., 1997; Okamoto et al., 2001). Many of them were called 'halophiles' in the original articles, but this is not entirely accurate. A more appropriate term for these microorganisms would be "marine and halotolerant psychrophiles" since their salinity optima occur at 3 $\% \mathrm{NaCl}(\mathrm{w} / \mathrm{v})$ and $12-15 \%$ salinity was the maximum limit for growth of these isolates. True halophiles inhabit brines with salt content as high as 10 times $(30 \% \mathrm{NaCl})$ the salinity of ordinary seawater. Apart from the green alga Dunaliella salina, almost all halophiles are archaea.

The lowest temperature for growth $\left(-2{ }^{\circ} \mathrm{C}\right)$ in marine polar ecosystems is recorded for the sulfate reducing bacteria, which were true psychrophiles and did not grow at room temperature (Knoblauch et al., 1999). The study of diversity and distribution of sulfate-reducing bacteria in permanently frozen Lake Fryxell in Antarctica had showed that at least four of the six major phylogenetic groups of sulfatereducing bacteria (Desulfovibrio, Desulfosarcina, Desulfotomaculum, Desulfobulbus, Desulfobacter, and Desulfobacterium) were present in the lake (Karr et al., 2005). All these cultures should be active at $4{ }^{\circ} \mathrm{C}$ that means psychrophilic or psychrotolerant physiology.

For halo-alkaliphilic species the observations in situ at temperatures as low as $-20{ }^{\circ} \mathrm{C}$ have been previously reported (Staley \& Gosink, 1999). Pure cultures of halophilic psychrophiles with optimum salinity $20 \%$ have not yet been obtained. Psychrobacter cryohalolentis $274-4^{\mathrm{T}}$ growing at $-10{ }^{\circ} \mathrm{C}$ and 
$10 \%$ salinity was described by Bakermans et al., (2006). This bacterium is not a true psychrophile but rather psychrotolerant, and was isolated from the permafrost of the Kolyma Lowlands in North Siberia. The same species was found in the ice covered Lake Fryxell of the Taylor Valley of Antarctica (Ryan et al., 2007).

In cold peat bogs of the Polar Regions, psychrophilic and psychrotolerant organo-hethero-trophic microbial communities developed the tolerance to high concentrations of organic acids, accumulated as a result of enormous activity of primary decomposers on the aerobic and anaerobic levels. The only explanation for this phenomenon is the predominance of activity for primary decomposers over the secondary ones. Perhaps during the process of sharp climatic changes, bacterial communities did not have time to increase the metabolic activity for the secondary decomposers that originally were mesophiles and had to mineralize the organic matter within the community at much higher temperatures. High concentration of organic acids that decrease the $\mathrm{pH}$ to $4-5$, could also be explained by the high metabolic acitivity of acetogens. Fungi are responsible for the aerobic decomposition of organic matter in such ecosystems, and it is well known that they are tolerant to moderately low $\mathrm{pH}$. Hughes and Bridge (2009) have reviewed the role of Antarctic fungi and yeasts in the bioremediation of hydrocarbons in Antarctica.

Franzmann et al. (1987) investigated the limnology and microbiology of Organic Lake, a shallow,

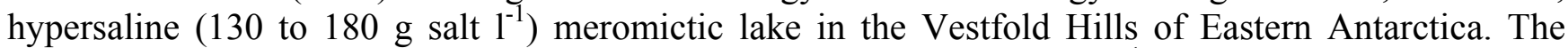
anoxic zone of Organic Lake has the highest concentration (up to $300 \mathrm{n} \mathrm{gl}^{-1}$ ) of dimethyl sulfide (DMS) recorded in a natural aquatic ecosystem. The species diversity of Organic Lake is very low, primarily consisting of halophilic microalgae Dunaliella sp. and archaea. They reported the isolation of a strain of the archaea Halomonas sp. that was capable of producing DMS from sulfur bearing amino acids. In addition to species of the Dunaliella, Roberts et al. (1993) reported detection of the diatom Chaetoceros sp. and the choanoflagellate Acanthaoecopsis unguiculata and strains of Halomonas sp. that produced dimethyldisulphide (DM2S) from methionine and cystreine. They concluded that the reduced sulphur volailes in the lake were primarily produced by anaerobic breakdown of algae by bacterial decomposition. Ward,and Priscu (1997) reported the detection of denitrifying bacteria in an ice-covered Antarctic Lake. Glatz et al. (2006) investigated the microbial diversity in the water column of permanently ice-covered Lake Bonney, Antarctica. Voytek, et al. (1998) used immunofluorescence, in situ hybridization and PCR analysis to determine the abundance of ammonia-oxidizing bacteria in this lake. The denitrification of the hypolimnion and the bacterial productivity in the anoxic zone of Lake Bonney was described by Ward et al. (2003, 2005).

Bowman (2001) obtained 16S rDNA clone libraries and studied the diversity of the bacteria and archaea of the anoxic sediments of meromictic lakes and coastal marine basins. They found little similarity between the phylotypes of the meromictic lake ecosystem with the phylotypes present in marine sediments and reported the detection of a wall-less Antarctic spirochaetes. Mulicki and Priscu (2007) investigated the diversity of bacteria in Blood Falls, an iron-rich ancient sub-glacial marine brine released beneath the Taylor Glacier in Antarctica. The dominant bacterium in the $16 \mathrm{~S}$ rRNA gene clone library of phylotypes from this unusual polar ecosystem had 99\% homology with Thiomicrospira arctica, a psychrophilic autotrophic sulfur oxidizer. Their clone library also indicated the presence of phylotypes of the division Bacteroidetes and classes Betaproteobacteria, Deltaproteobacteria, and Gammaproteobacteria. The glacier hydrology, lithology and preglacial ecosystem apparently controlled the metabolic and phylogenetic structure of this subglacial ecosystem, with the growth supported by the chemical energy of the reduced sulfur and iron compounds. Perreault et al. (2007) concluded that sulfur compounds were the major energy source for the ecosystem of the 
perennially cold saline springs at Gypsum Hill and Colour Peak on Axel Heiberg island in the Canadian High Arctic.

The first moderately acidophilic true psychrophiles were isolated from tundra permafrost soils (Dedysh et al., 2000). All three methanotrophic species of the genus Methylocella tolerate acidic $\mathrm{pH}$ at 4.5 and grow in the temperature regime of psychrophiles (Dunfield et al., 2003; Dedysh et al., 2004).

Many alkalitolerant psychrophilic or psychrotolerant bacterial species have been described, but none of them were truly alkaliphilic. The study of the unique new ecosystem in Ikka Fjord, Greenland, lead to the isolation of first true alkaliphilic psychrophilic bacterium Rhodonellum psychrophilum $\mathrm{GCM} 71^{\mathrm{T}}$. This novel strictly aerobic and red pigmented bacterium was isolated from the interior seep water in alkaline ikaite tufa columns (Schmidt et al., 2006). It was found to be very distant from all known species, and it is located on a new separate taxonomic lineage on the genus and species levels. This isolate has optimal growth at $\mathrm{pH} 9.2-10.5{ }^{\circ} \mathrm{C}$, and $0.6 \% \mathrm{NaCl}$. The maximum $\mathrm{pH}$ for its growth was determined at 10.7 and the minimum temperature for growth at $0{ }^{\circ} \mathrm{C}$. The same group (Schmidt et al., 2007) recently described a new genus and species of marine psychrophilic alkaliphile Arsukibacterium ikkense GCM72 ${ }^{\mathrm{T}}$. These two new "champion extremophiles" with growth at high $\mathrm{pH}$ and low temperature (R. psychrophilum and A. ikkense) are shown in the updated $\mathrm{pH} /$ temperature and $\mathrm{NaCl} /$ temperature diagrams.

\section{EXTREMOPHILES WITHIN PHYSICO-CHEMICAL MATRIX}

The distribution of validly published species of extremophiles was previously presented by us in matrix form (Pikuta et al., 2007). These diagrams have been updated in accordance with recent discoveries and are presented here as matrix of: $\mathrm{pH} /$ temperature (Fig. 1.a); pH/salinity (Fig. 1.b) and temperature/radiation (Fig. 1.c). According to these diagrams, the prokaryotic extremophile that grows at the lowest temperature $\left(-10{ }^{\circ} \mathrm{C}\right)$ and $10 \%$ salinity currently known is the psychrotolerant mesophilic species Psychrobacter cryohalolentis, which was isolated from the permafrost of the Kolyma Lowlands of North Siberia (Bakermans et al. 2006). Psychrobacter submarinus is the most halotolerant true psychrophile growing around $15 \%$ salinity (Romanenko et al., 2002). The true halophilic species within psychrophiles remain undiscovered. Methanotrophic psychrophilic species of the genus Methylocella tolerate acidic $\mathrm{pH}$ at 4.5 , but the mesophilic species Acidiphilum acidophilum tolerates $\mathrm{pH}$ 1.5 at $15{ }^{\circ} \mathrm{C}$ (the minimum temperature for growth). True psychrophilic acidophiles are unknown or, most probably, do not exist at all. The alkaliphilic psychrophiles, Rhodonellum psychrophillum and Arsukibacterium ikkense, are the "champions" growing at $\mathrm{pH} 10.5$. We now know that the mesophilies (rather than psychrophilic or psychrotolerant species) have the highest environmental limits for salinity and pH (Fig. 2a \& Fig. 2b).

There are very few known psychrophilic bacteria or archaea that tolerate high levels of gammaradiation (Fig. 2c). Callegan et al., 2008 described four new species of true psychrophiles of the genus Deinococcus isolated from soil from high alpine environments. However, these species were not as resistant to radiation as the type species of this genus $D$. radiodurans.

In terms of either biomass or the number of cells, the majority of the psychrophiles on Earth are the barophilic bacteria and archaea that inhabit the deeper layers of the oceans, which cover almost $75 \%$ of the surface of our planet. 


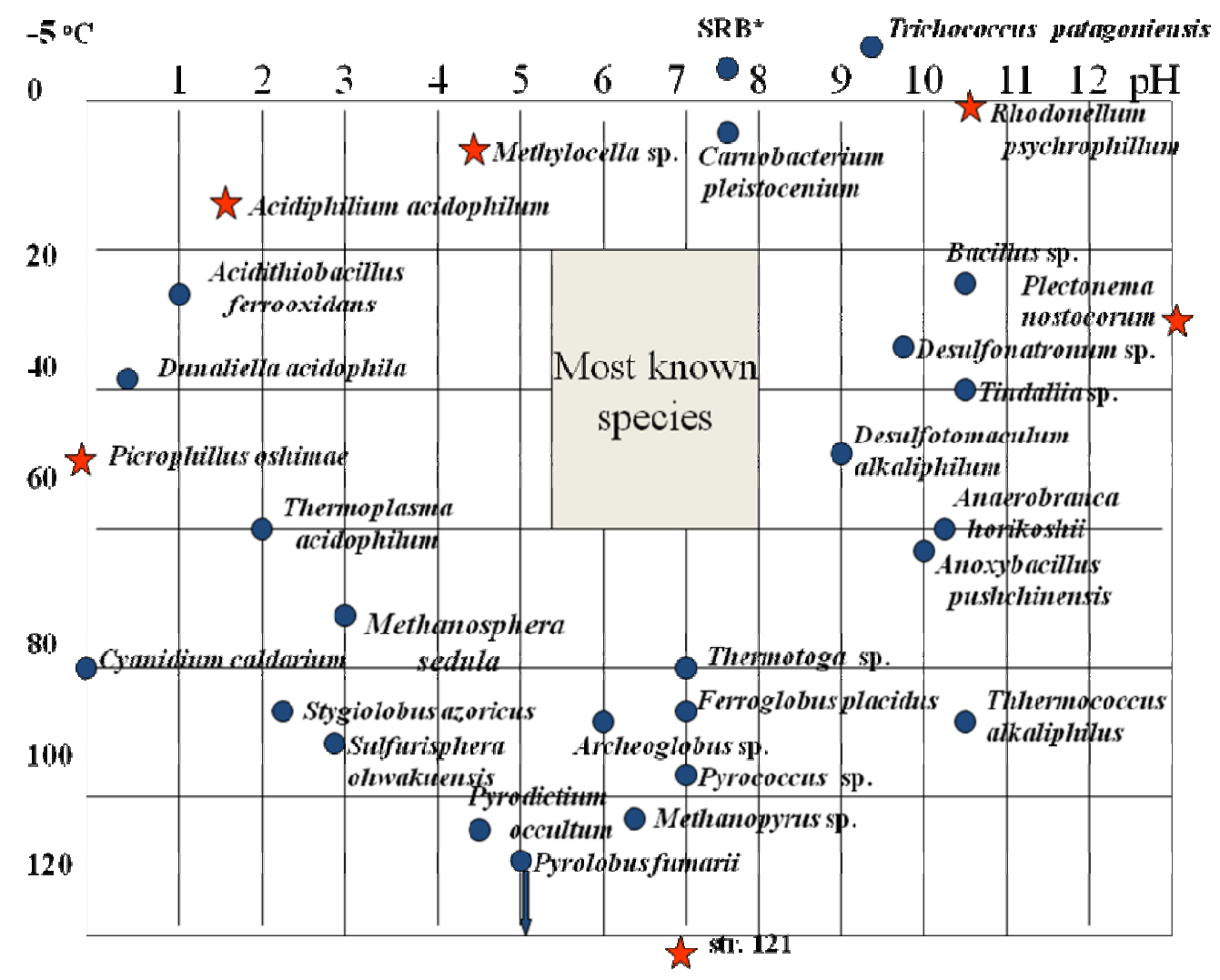

a

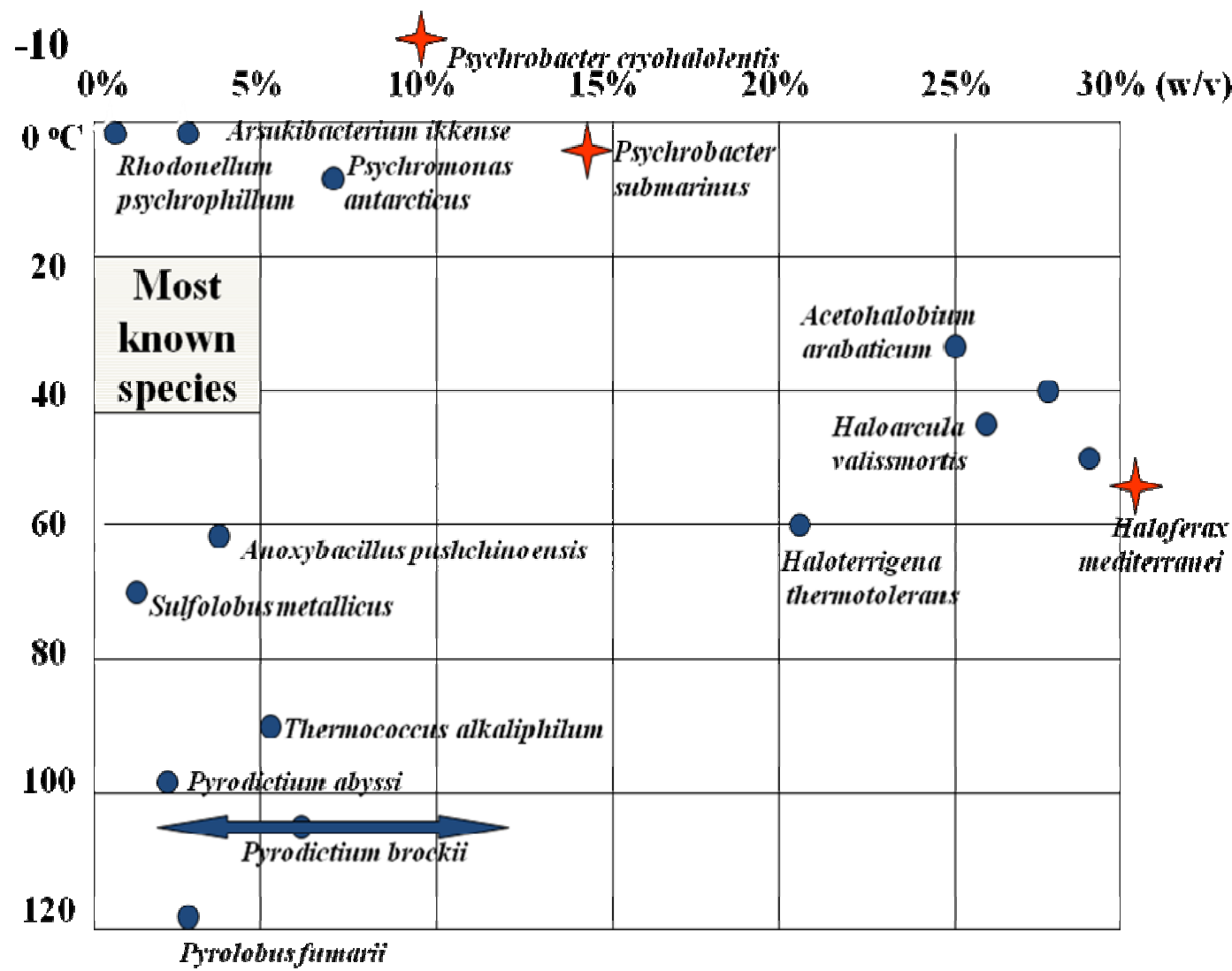

b. 


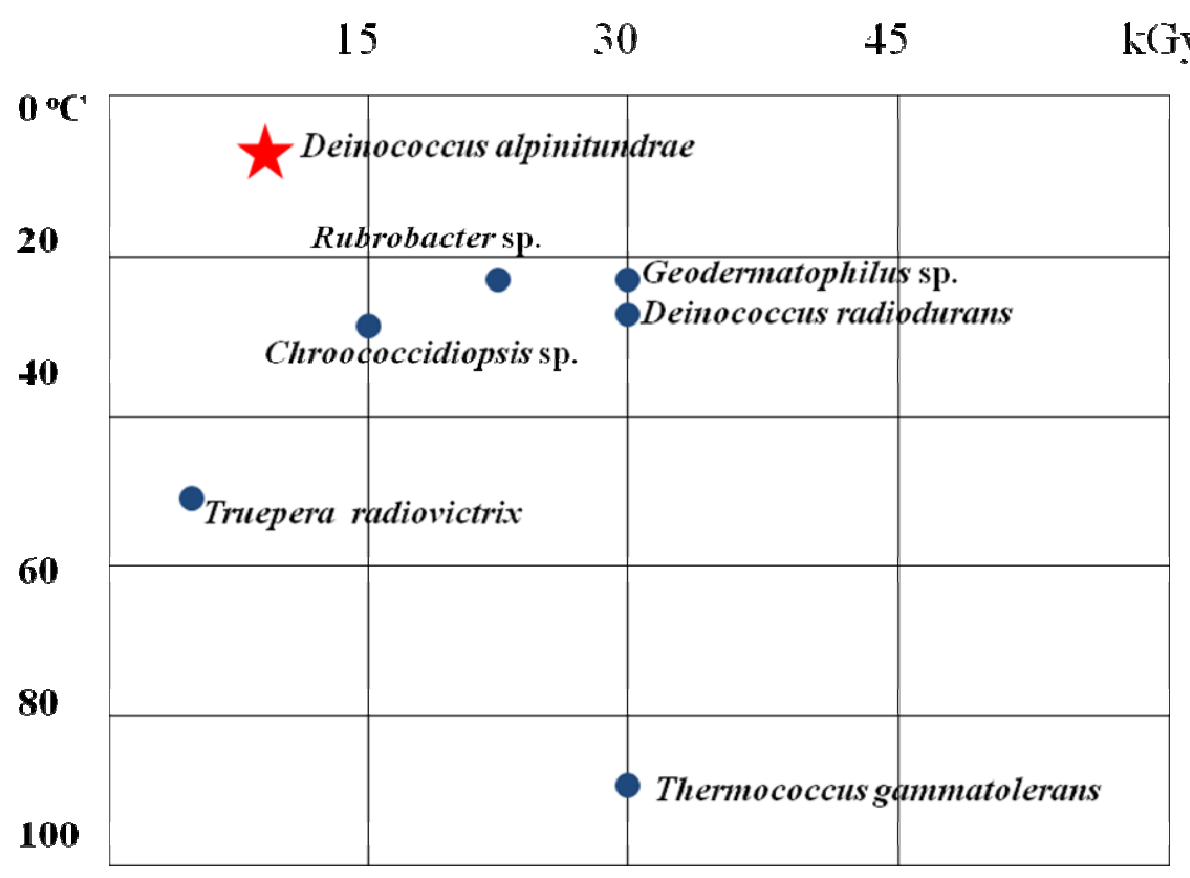

c.

Fig. 2. Diagram of all known validated microorganisms distributed within a. matrix $\mathrm{pH} /$ temperature.

$\left(^{*}\right.$ - species of five genera of psychrophilic sulfate-reducing bacteria); b. $\mathrm{NaCl}$-salinity/temperature; and c. matrix temperature/gamma-radiation.

We would like to highlight that currently among psychrophilic bacteria there have been found only neutrophilic, alkaliphilic and halotolerant species. The absence of acidophilic psychrophiles remains intriguing. From the cold acidic (pH 1-2) environments the only known acidophiles that have been described are psychrotolerant mesophiles. The true psychrophilic moderate acidophiles, such as species of the genus Methylocella, tolerate only pH 4.5 to 5. This leads to questions: Does Nature keep a restriction on the combination of the genes for psychrophily and acidophily? If so---Why? Was it because low-temperature and acidic environments have not co-existed on Earth long enough for evolutionary processes to adjust the genome for supporting life? Or is it because microorganisms capable of inhabiting such environments are extinct or have not yet been discovered? The most likely places to search for such ecosystems are acidic veins in glacial ice (Price, 2000) and beneath glaciers on volcanic peaks such as Mt. Erebus in Antarctica. Another, intriguing question: Is it possible to create such combination of genes artificially in the laboratory? Investigations in the near future may possibly answer these questions.

\section{ANAEROBIC EXTREMOPHILES FROM POLAR EXPEDITIONS}

During the past decade, the NASA/MSFC/NSSTC Astrobiology group organized field expeditions and samples anaerobic extremophiles from several polar and sub-polar regions of Earth. These included expeditions to:

Matanuska Glacier and Fox Permafrost Tunnel, Alaska $(1998,1999,2008)$

Kolyma Lowlands of North Siberia - International Expedition "Beringia" (1999)

Patriot Hills, Thiel Mountains \& South Pole, Antarctica - "Antarctica 2000 Expedition"

Patagonia, Chile - "Antarctica 2000 Expedition"

South Africa; Schirmacher Oasis, Lake Untersee \& Anuchin Glacier, Antarctica "2008 International Schirmacher Oasis/Lake Untersee, Antarctica Expeditions 
A number of anaerobic bacteria were isolated and characterized from samples obtained during these field expeditions. We review a few interesting microbial extremophiles isolated from these samples.

\subsection{Novel Psychrotolerant Extremophiles from Expeditions to Alaska}

\subsubsection{Pleistocene Bacterium from Fox Permafrost Tunnel}

The study of permafrost samples from Alaska led to discovery of the psychrotolerant Carnobacterium

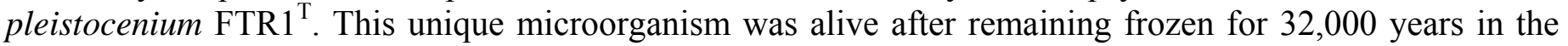
ice of a Pleistocene Thermokarst Pond of the Cold Regions Research and Engineering Laboratory (CRREL) Permafrost Tunnel at Fox, Alaska. The first study of the geology of the Fox Tunnel was performed by Sellman in 1967. Accurate measurement of the ages of the strata in the Fox Tunnel were received by radiocarbon dating of wood from the tunnel using the high sensitivity liquid scintillation counting method (Long and Pewe, 1996). The paleo-ecology and the distribution of the taxa of all found fossils of flora and fauna in the Fox Permafrost Tunnel were described in detail by Hamilton et al. (1988). A diagram of the geological cross section is shown in Figure 3.

\section{CRREL Permafrost Tunnel in Fox, Alaska}

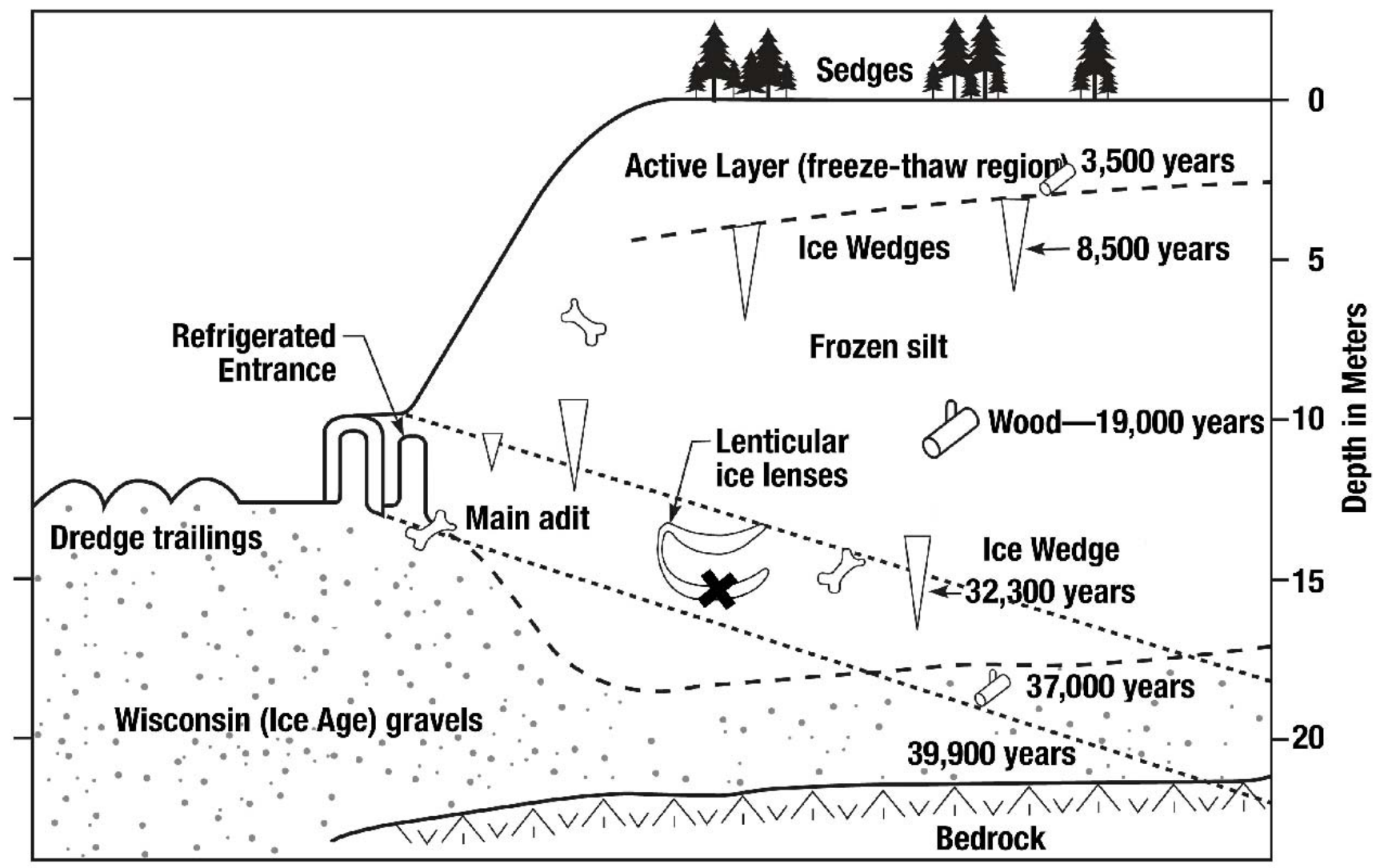

Fig. 3. Cross-section diagram showing the geology of the Fox Permafrost Tunnel with paleontological records. The cross shows the sampling location.

This facultatively anaerobic fermenting bacterium was described as a separate new species since it was different from known species both on genetic and phenotypic levels (Pikuta et al., 2005). Like most other species of the genus Carnobacterium, the new strain FTR $1^{\mathrm{T}}$ showed psychrotolerant physiology and demonstrated the ability to grow at $0{ }^{\circ} \mathrm{C}$ (Fig. $4 \mathbf{a} \& \mathbf{b}$ ). 


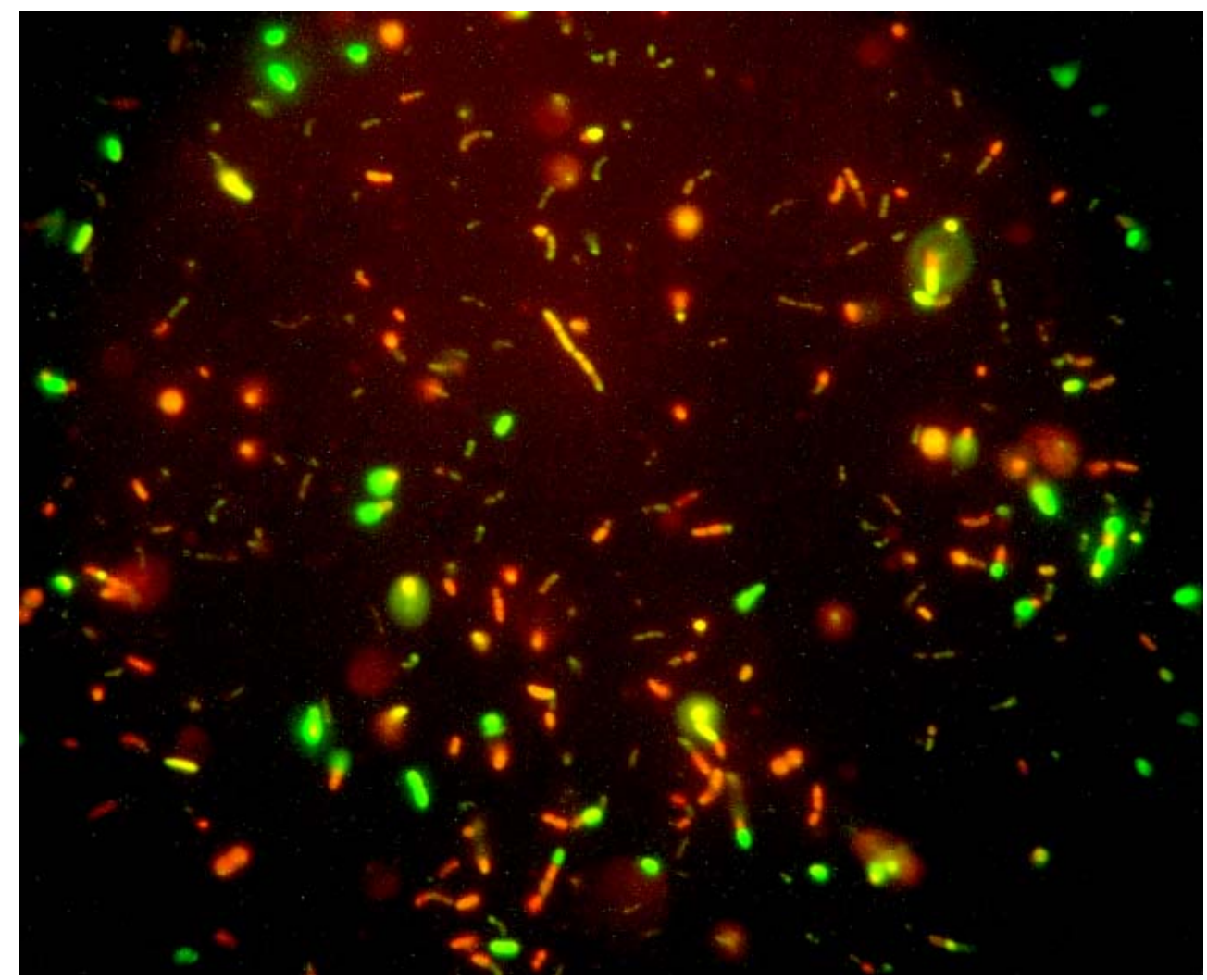

a.

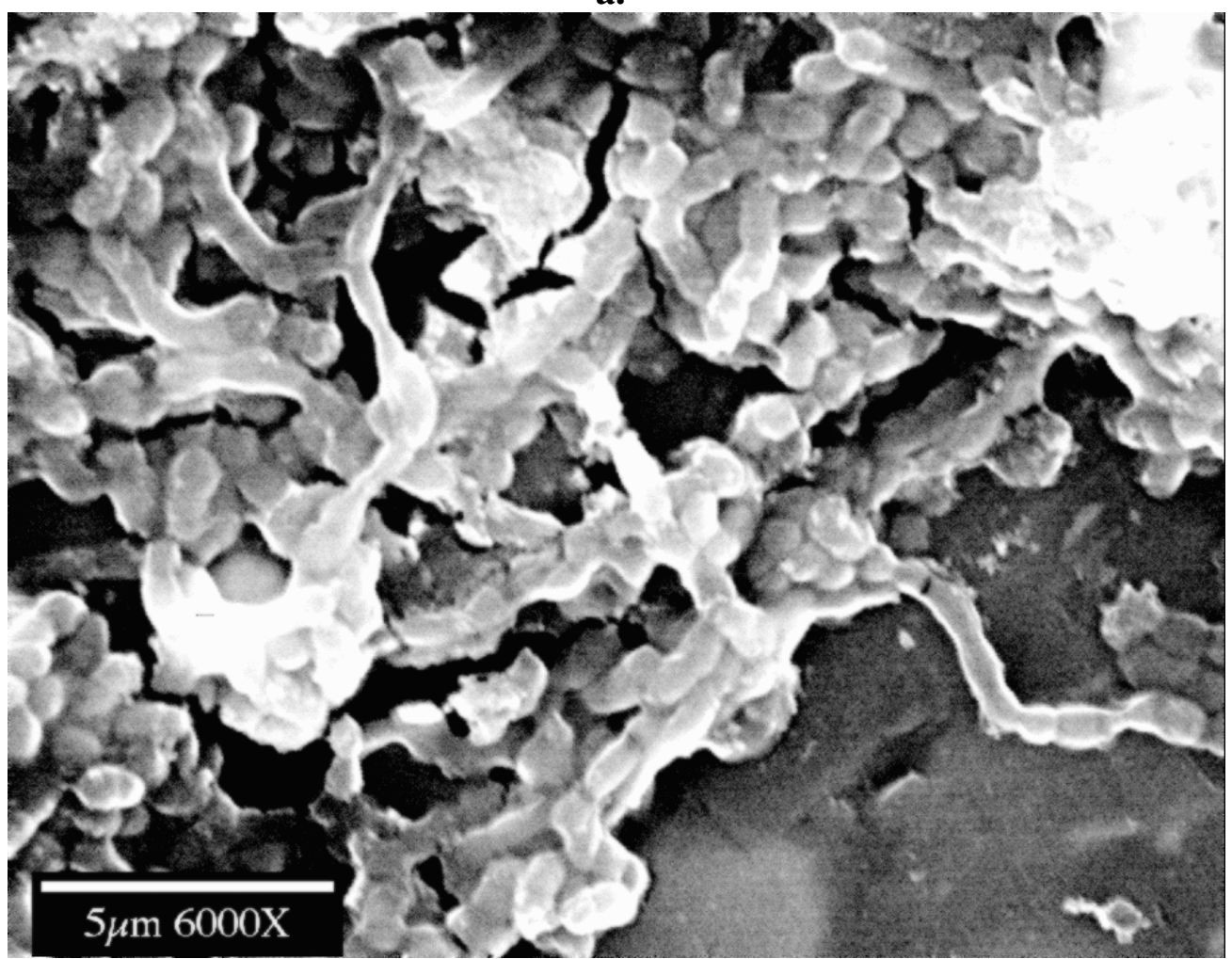

b.

Fig. 4. Images of strain FTR $1^{\mathrm{T}}$ with: a. BacLite live/dead stain (Photo by Prof. A.K. Bej, UAB); b. Hitachi S4000 Field Emission Scanning Electron Microscope, scale bar is $5 \mu \mathrm{m}$. (Photo by Greg Jerman, MSFC). 
Strain FTR $1^{\mathrm{T}}$ was neutrophilic (optimum growth at $\mathrm{pH} 7$ ) and had an alkalitolerant nature (growth observed at $\mathrm{pH}$ 9.5). The optimum temperature for growth was $24{ }^{\circ} \mathrm{C}$ (maximum $28{ }^{\circ} \mathrm{C}$ ). The $\mathrm{NaCl}$ range for growth was $0-5 \%(\mathrm{w} / \mathrm{v})$, optimal concentration of $\mathrm{NaCl}$ was $0.5 \%$. The chemo-organotrophic metabolism of this bacterium with ability to utilize sugars and proteolysis products is typical for all known species of this genus. The main metabolic end products were: acetate, ethanol, and $\mathrm{CO}_{2}$. This strain was sensitive to all antibiotics tested, that confirms its wild origin.

All known species of the genus Carnobacterium are facultative anaerobes and as was reported by Franzmann et al., 1991. They are capable of reducing resazurin in aerobic media during growth. It is quite possible that in nature these organisms play the role of primary agents responsible for changing the redox potential in ecosystems by the reduction of the oxygen level and as result create conditions that are suitable for the development of obligately anaerobic microorganisms.

This bacterium is of great importance to both Astrobiology and Paleontology. It is first validly published species of a living bacterium from the Pleistocene that had been cryopreserved in ancient permafrost. It is also important to Astrobiology and cryobiology as it demonstrates potential relevance to water ice containing bodies of our Solar System. The presence of viable microbial cells in ancient ice suggests that future space missions may be able to extract ancient cryopreserved and possibly still living microorganisms from the surface crusts of icy moons of Jupiter or Saturn or the permafrost, craters, or Polar Ice Caps of Mars.

\subsubsection{Novel Acidophile from Chena Hot Springs}

The obligately acidophilic strain $\mathrm{AGC}^{\mathrm{T}}$ was isolated in pure culture (Pikuta and Hoover, 2004) from the Chena Hot Springs in Alaska. The sample was collected from dark-red mud at the bottom of a 0.5 $\mathrm{M}$ diameter $65{ }^{\circ} \mathrm{C}$ pool near the main spring. This mesophilic, spore-forming strain is able to grow on the medium with high concentrations of $\mathrm{Fe}^{2+}$ with $\mathrm{pH}$ 1.5-2.0. The taxonomic description of this bacterium is currently in preparation.

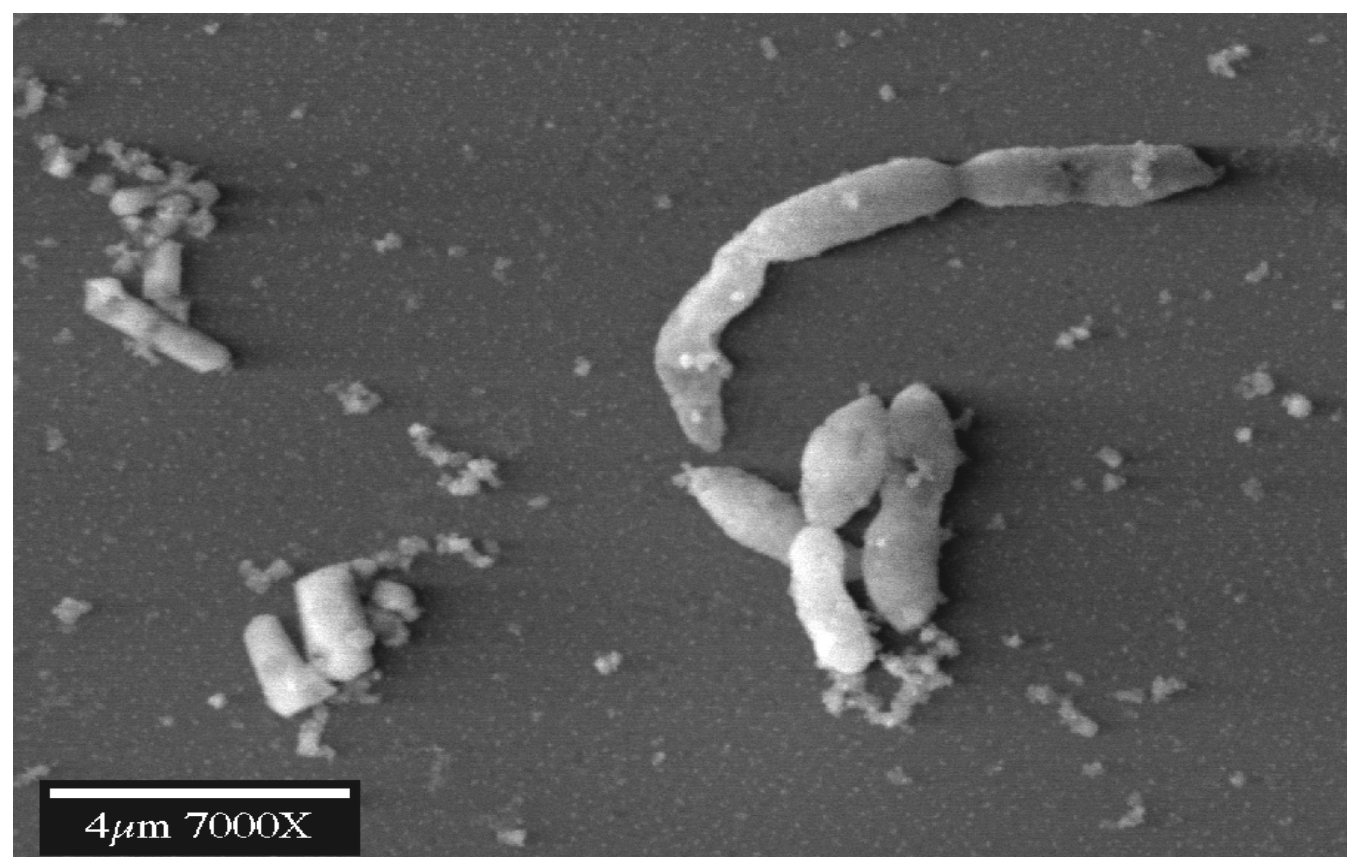

Fig. 5. Cell morphology of strain AGC-2 ${ }^{\mathrm{T}}$. 
Morphology of strain AGC-2: Cell sizes are $0.6 \times 1.2-2.0 \mu \mathrm{m}$, shape of cells is straight or slightly curved rods with rounded ends (Fig. 5). Cells are Gram- positive, motile, endospore-forming with swollen sporangium (only one spore per cell), and the spores have subterminal location. The cells multiply by binary division and occur singly, in pairs, or in short curved chains.

Physiology of strain AGC-2: Strictly aerobic, obligately acidophilic (no growth at $\mathrm{pH} 4.0$ ), mesophilic with optimum of growth at 29-32 ${ }^{\circ} \mathrm{C}$. Mixotroph (using $\mathrm{CO}_{2}$ and yeast extract for anabolism). No growth on peptone and $D$-glucose. On agarose medium it grows only with $\mathrm{Fe}^{2+}$ and yeast extract.

Cell-membrane lipids contain only $2 \%$ of the $\omega$-alicyclic fatty acids, which are typical for species of the genus Alicyclobacillus. The amount of $\mathrm{G}+\mathrm{C}$ in genomic DNA is $60.7 \mathrm{~mol} \%$. The strain AGC-2 was deposited in American Type Culture Collection and Japanese Collection of Microorganisms with corresponding numbers: ATCC BAA $-757^{\mathrm{T}}\left(=\mathrm{JCM} 12177^{\mathrm{T}}\right)$. The GenBank deposition number for this sequence is AF 450135 .

Phylogenetic analysis of strain AGC-2 ${ }^{T}$ : The $16 \mathrm{~s}$ rRNA gene sequence (Fig. 6) showed a position distant from all known species of the genus Alicyclobacillus and other species.

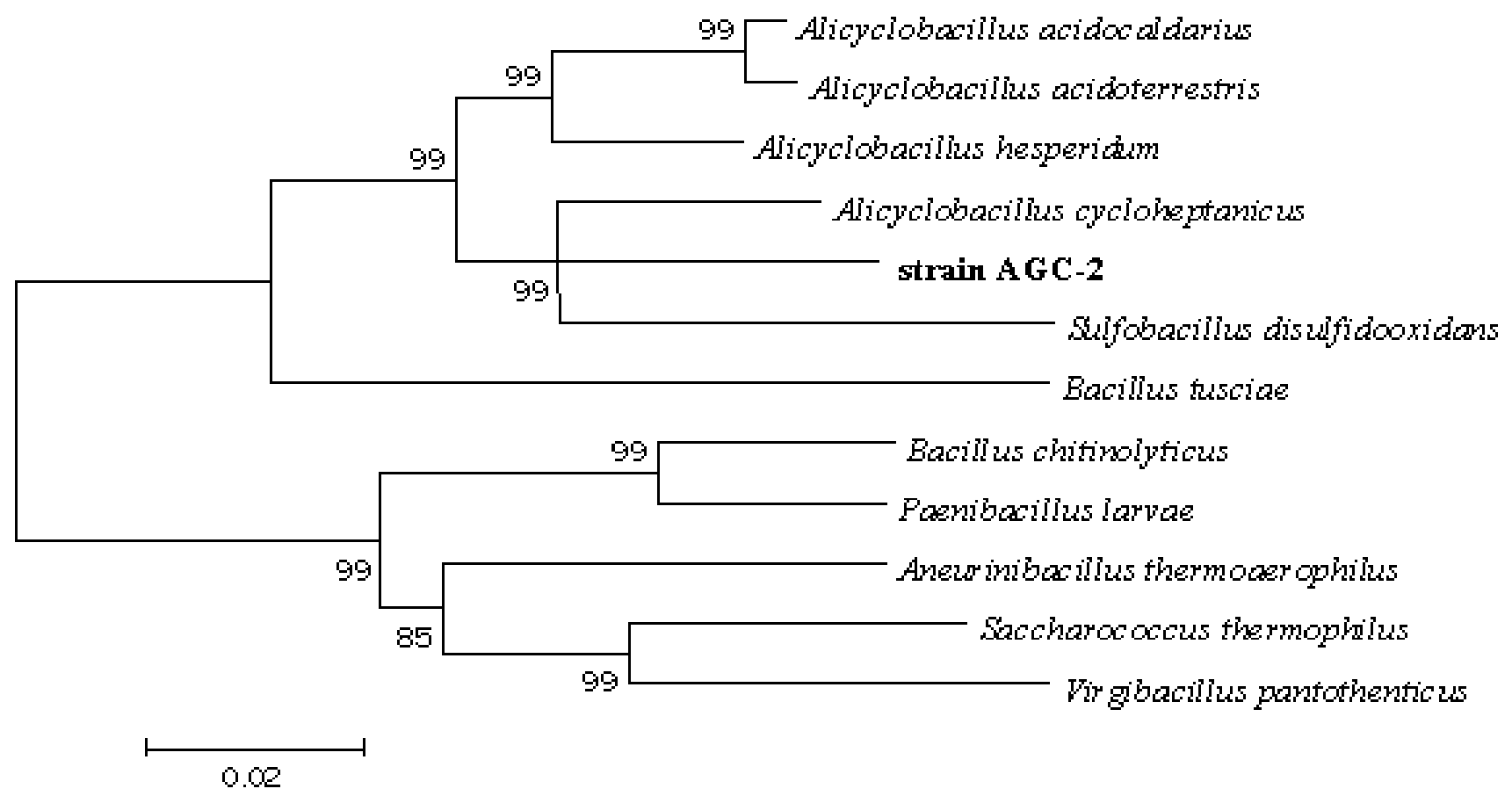

Fig. 6. Phylogenetic tree showing position of strain $A G C-2^{\mathrm{T}}$ among closest species.

\subsection{Novel Extremophiles from Antarctica 2000 Expedition}

5.2.1 Psychrotolerant Bacteria from Magellanic Penguin Colony in Southern Patagonia, Chile

Another interesting psychrotolerant sugarlytic bacterium was isolated from a sample of Magellanic Penguin (Fig. 7) guano collected from the bottom of a tidal pool in Southern Patagonia, Chile. Trichococcus patagoniensis $\mathrm{PmagG} 1^{\mathrm{T}}$ has the ability to grow at $-5{ }^{\circ} \mathrm{C}$ at both aerobic and anaerobic conditions (Pikuta et al., 2006). 


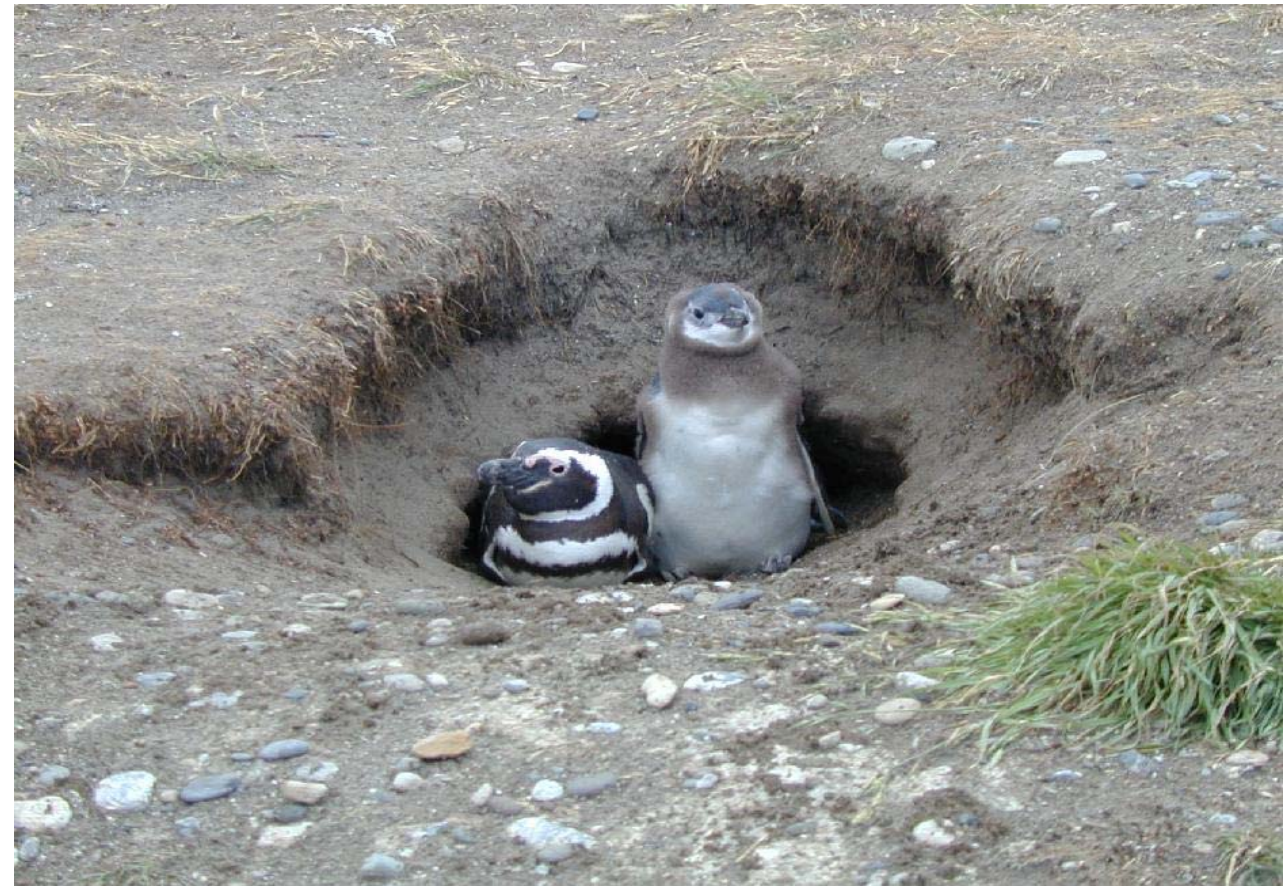

Fig. 7. Magellanic penguins in Patagonia, Chile.

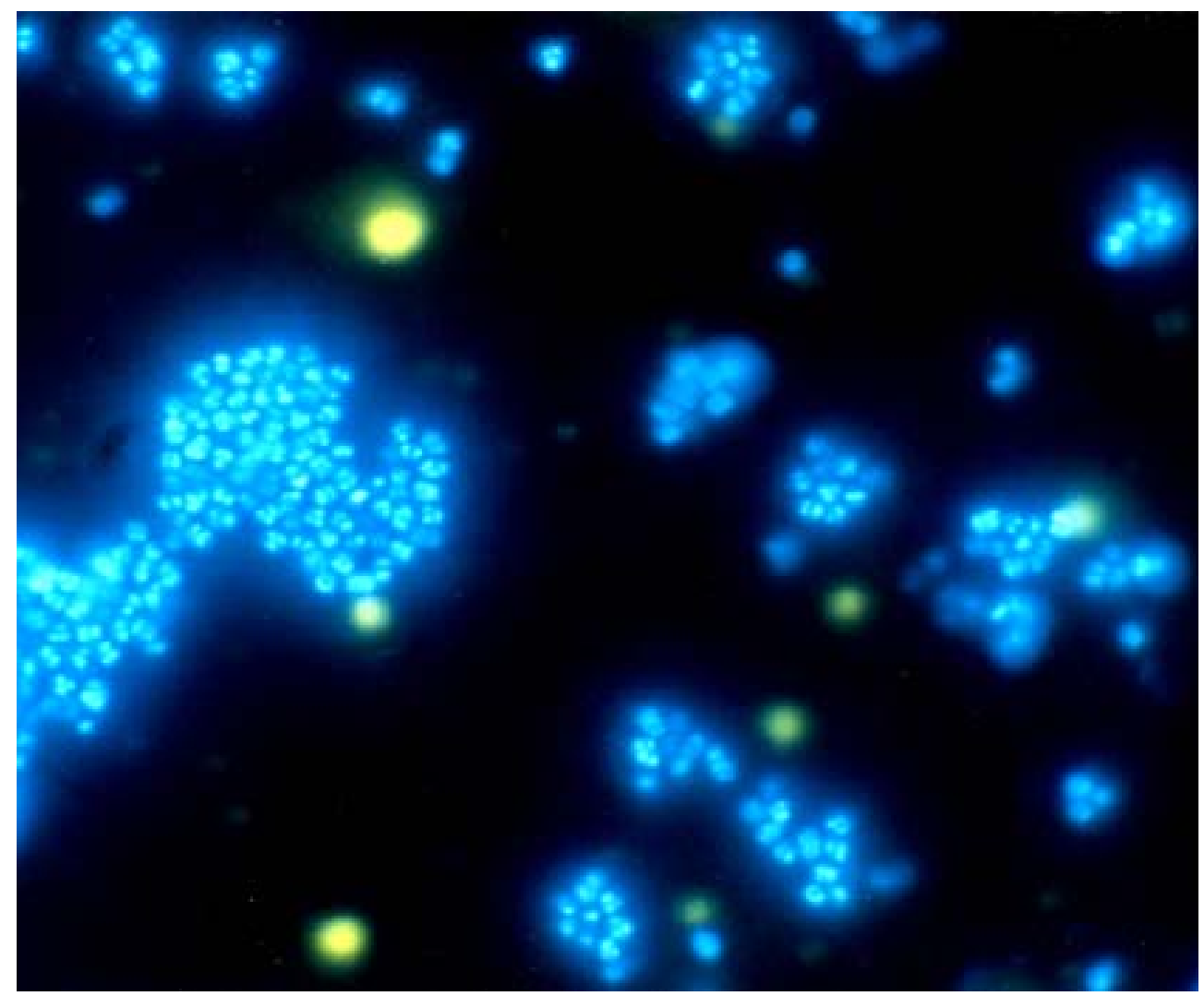

Fig. 8. Image of strain PmagG $1^{\mathrm{T}}$ grown at $3{ }^{\circ} \mathrm{C}$ with: a. DAPI stained cells under a Leitz Diaplan epifluorescent microscope: clumps of cells, single and cells in pairs are occur in the culture at the end of exponential growth phase. (Photo by Prof. A.K. Bej, UAB) 
The cells of strain PmagG1 ${ }^{\mathrm{T}}$ grown at $-5{ }^{\circ} \mathrm{C}$ have a tendency to excrete a capsule, composed of a mucopolysaccharide matter, surrounding their cell surface (Fig. 8). This probably allows this microorganism to keep the water in liquid state for metabolic functions in freezing conditions. Strain PmagG1 ${ }^{\mathrm{T}}$ was a catalase-negative facultative anaerobe, with $\mathrm{pH}$ range 6.0-10.0, and optimum for growth at $\mathrm{pH}$ 8.5. It did not require $\mathrm{NaCl}$ for growth, but had optimum at $0.5 \% \mathrm{NaCl}$ and it could tolerate $6.5 \%$ salinity. The temperature range for this organism was -5 to $35^{\circ} \mathrm{C}$, and optimum growth was observed at $28-30{ }^{\circ} \mathrm{C}$. Strain PmagG $1^{\mathrm{T}}$ had heterotrophic metabolism, and could utilize as substrates some sugars and some organic acids (pyruvic and citric). The metabolic end products were: lactate, formate, acetate, ethanol (in cultural liquid), and $\mathrm{CO}_{2}$ in the gas phase. It was sensitive to all antibiotics checked, indicating the wild origin of this strain.

During the study it was shown that all species of the genus Trichococcus have psychrotolerant physiology with highly stable genomic memory: the sequences of $16 \mathrm{~S}$ rRNA had very close similarity up to $100 \%$ by the pair-wise distance. This may indicate that the psychrotolerant features of these species evolved to adapt to low temperatures a long time ago and are tightly related conservative genetic units (chromosomal DNA).

The taxonomical description of the proteolytic, spore-forming, psychrotolerant bacterial strain $\mathrm{PPP}^{\mathrm{T}}$ that represents a separate new genus and species Proteocatella sphenisci was completed recently (Pikuta et al., 2009). The cells were motile rods, endospore-forming, and gram-positive (Fig. 9).

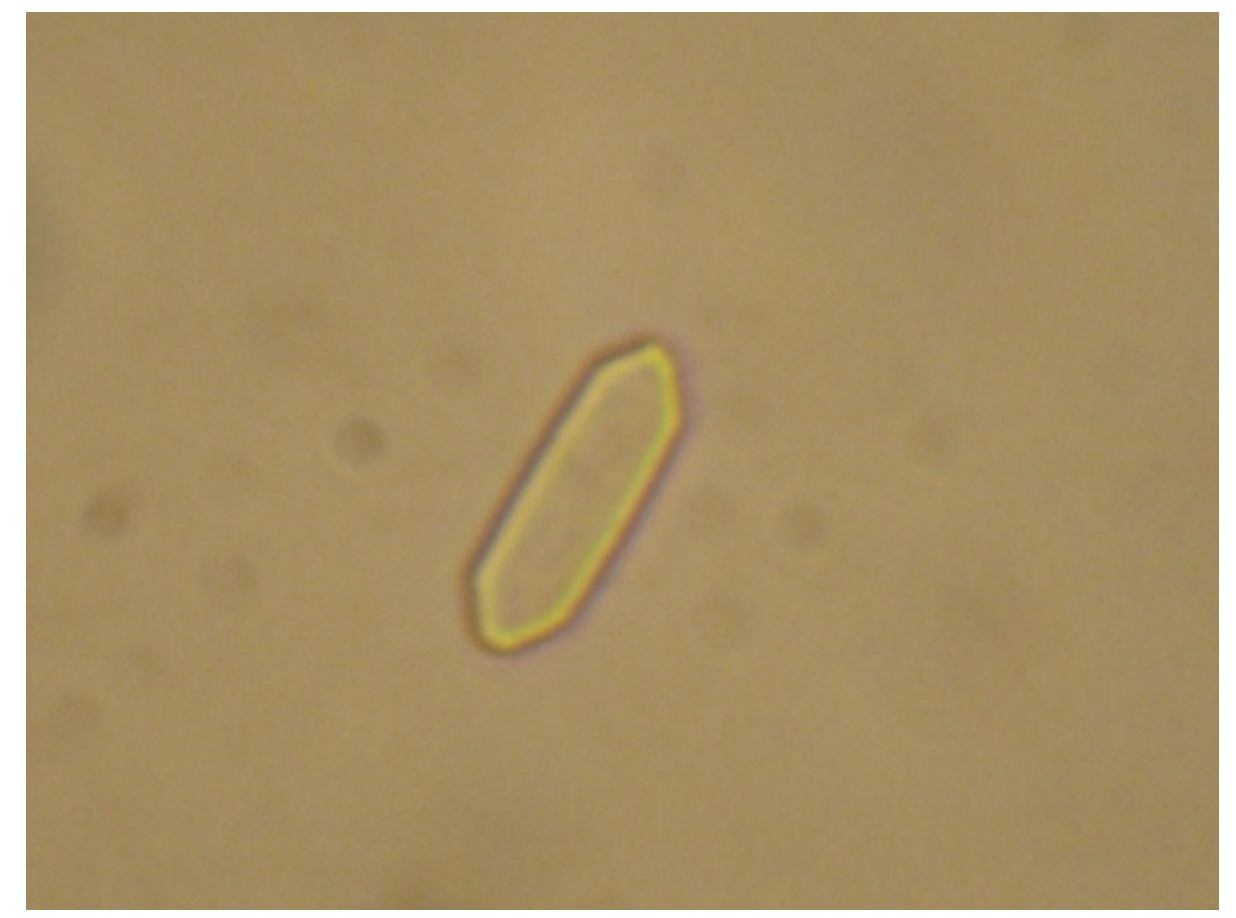

Fig. 9. Atypical morphology of the cells of strain PPP2 $2^{\mathrm{T}}$ grown on sodium oxalate $\left(3 \mathrm{~g} \mathrm{^{-1 }}\right)$. It is interesting that although the cells looks like hexagonal crystals, they were motile by flagella. .

Strain PPP $2^{\mathrm{T}}$ had the ability to grow exclusively on proteolysis products (peptone, casamino acids, yeast extract), and oxalate. It was unable to grow on separate amino acids nor perform respiration by the Stickland reaction. The main end product of metabolism was acetate; traces of $\mathrm{CO}_{2}$ and $\mathrm{H}_{2}$ were gas minor products. Minimum temperature for growth was determined at $2{ }^{\circ} \mathrm{C}$. New isolate was found to belong to Clostridial cluster XI and it had distant position on the level of separate genus and species. 
5.2.2 Novel Psychrophilic and Psychrotolerant Anaerobes from Patriot Hills, Antarctica

Strain LL-8 was isolated from the sample collected in the Patriot Hills during the Antarctica 2000 Expedition. This strain had features of dimorphic prosthecate type bacteria, and it was difficult to cultivate. It slowly grew during 2 to 3 months at $3{ }^{\circ} \mathrm{C}$ on medium with peptone $\left(3 \mathrm{~g} \mathrm{l}^{-1}\right)$ and yeast extract $\left(0.1 \mathrm{~g}^{-1}\right)$. The optic density of the grown enrichment culture never exceeded 0.3 absorption at $\lambda=510 \mathrm{~nm}$. The transfer on the medium with the small quantity of the substrates $\left(0.02 \mathrm{~g}^{-1}\right)$, which is typical for Caulobacter-like bacteria, did not show growth of the culture.

Strain LL-8 had the unusual morphology of straight rods with tendency of rectangular cell division forming orthogonal, acute or obtuse junctions as the cells/prosthecae divided (Fig. 10a, b).

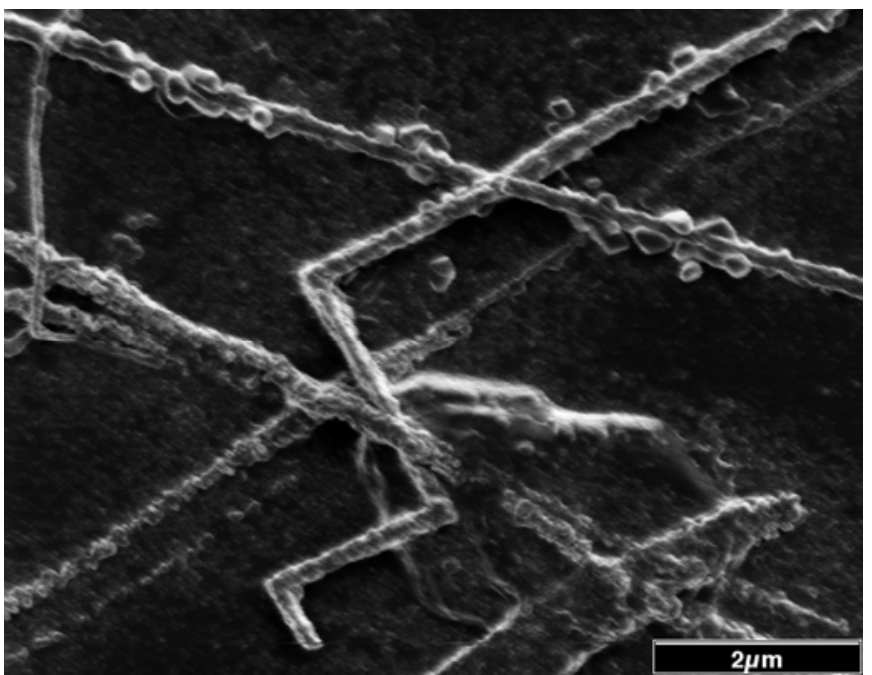

a.

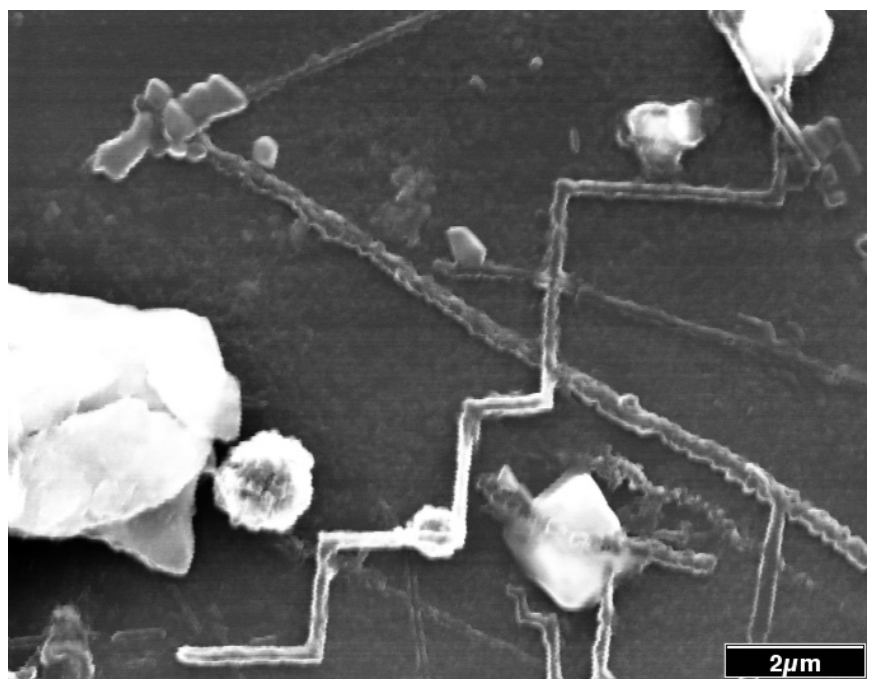

c.

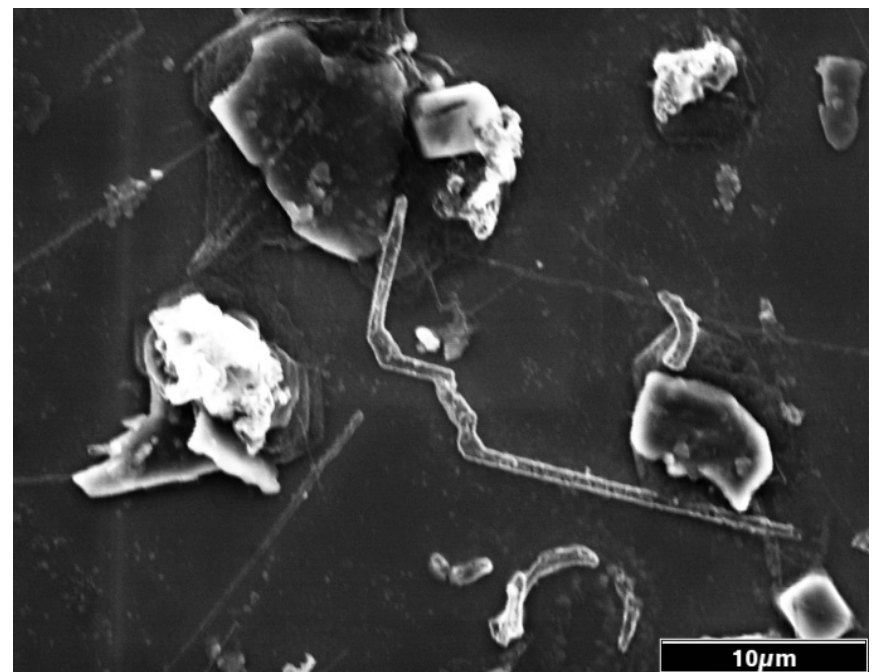

b.

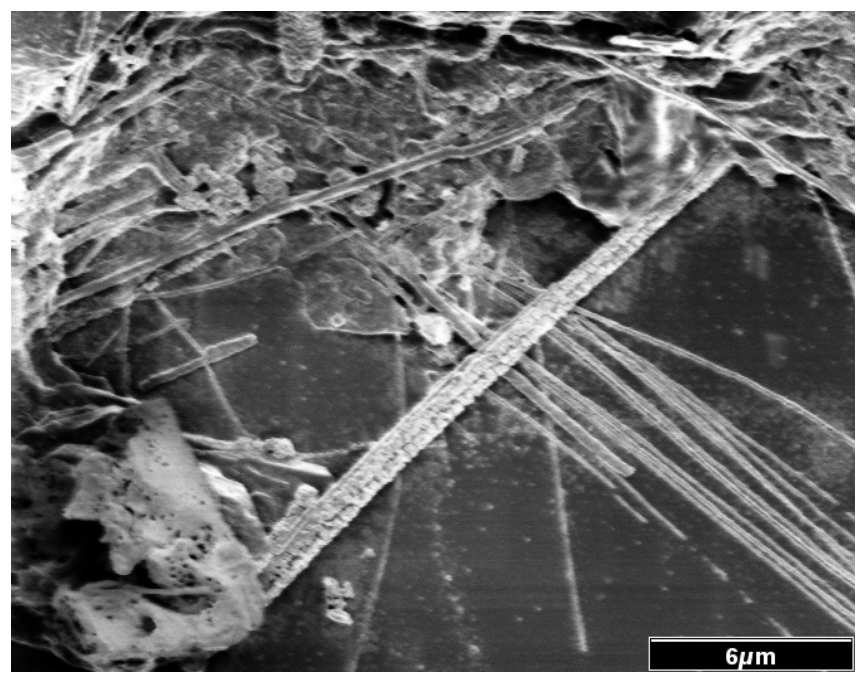

d.

Fig. 10. Electron scan microscopy of strain LL-8: a straight and rectangularly bended prosthecae; $b$ cells and bended prosthecae; c Spores and prosthecae, on right lower corner the Y-type bifurcation of the prostheca is shown; $d$ the fragment of 'fury ball' rays on right lower corner. 
Strain LL-8 was spore-forming rods with prosthecae extending up to 20-25 $\mu \mathrm{m}$. Sometimes star-shape "fury balls" with sizes 100-200 $\mu \mathrm{m}$ could be observed with many straight long stalks or prosthecae (Fig. 10d). It is interesting that the diameter of the prosthecae varied from 0.2 to $0.8 \mu \mathrm{m}$, and sometimes the the thicker prosthecae exhibited a shiny reflective material covering the surface. This shiny reflecting cover was not observed in the thin prosthece. Gram-staining of strain PPP2 $2^{\mathrm{T}}$ cells demonstrated positive reaction. Spores were round with diameter twice that of the cells (Fig. 10c), the sporangium was not swollen. The morphology of strain LL-8 is unlike that of the known described species of the genera Caulobacter, Asticcacaulis, Hyphomicrobium, Pedomicrobium, Hyphomonas, or Thiodendron. Sometime the dichotomic devision of prosthecae with Y-type bifurcation could be observed during microscopy of strain LL-8 (Fig. 10d).

Strain PH-21 was also isolated from the sample collected at the Patriot Hills, Antarctica. The morphology and other phenotypic features of this strain were similar to strain PmagG1 ${ }^{\mathrm{T}}$. The only difference was found in the spectrum of substrate utilization, as well as slightly smaller sizes of cells. Phylogenetic analysis of strain PH-21 showed $100 \%$ similarity with the sequence of strain $\mathrm{PmagG1}^{\mathrm{T}}$. The DNA-DNA-hybridization analysis of these two strains will confirm the taxonomic position for strain PH-21.

\subsection{Tawani International Antarctica Expeditions}

The 2008 Tawani International Schirmacher Oasis/Lake Untersee, Antarctica Expeditions were conducted as a part of the 2008 International Polar Year. The scientific focus of these two Antarctic expeditions was the investigation of microbial extremophiles and the biodiversity of the lakes and ice of the Schirmacher Oasis and Lake Untersee. The Reconnaissance Expedition was a brief 10 day mission in February, 2008. It was carried out by five members of the international team to the Schirmacher Oasis and Lake Untersee, Antarctica. (Hoover et al., 2008). A number of anaerobic microbial cultures were obtained. The samples collected were returned to the NSSTC Astrobiology Laboratory for studies of the anaerobic extremophiles. Samples were distributed to other team members (Asim Bej, Birgit Sattler and Michael Storrie-Lombardi) for investigations of aerobic microorganisms. The validated bacterium capable of growth at $-5{ }^{\circ} \mathrm{C}$ (Trichococcus patagoniensis) that was isolated from Magellanic Penguin (Spheniscus magellanicus) guano collected during the Antarctica 2000 Expedition led us to investigate guano samples from the African Penguin (Spheniscus demersus), which also resulted in the detection of interesting novel psychrotolerant anaerobic bacteria.

\subsubsection{Psychrotolerant Anaerobes from the African Penguin guano}

The African Penguin Spheniscus demersus is the only species of penguin that breeds around the South African coast (Fig. 11a). Environmental samples of the penguin guano were collected from a small tidal pool with the assistance of Park Rangers at the Stony Point Nature Reserve, Betty's Bay, South Africa (S $34^{\circ} 21^{\prime} 25^{\prime}$; E $\left.18^{\circ} 28^{\prime} 16^{\prime \prime}\right)$. The samples collected had $\mathrm{pH} 6.8$, salinity $3 \%$, and at the moment of collection the water temperature was $15^{\circ} \mathrm{C}$. The sample was immediately examined by visible light, dark field microscopy and then returned directly to the NSSTC Astrobiology Laboratory in Huntsville. Phase Contrast microscopy of the sample at NSSTC showed the presence of diverse motile microbial cells $\left(\sim 10^{13}\right.$ cells per $\left.\mathrm{ml}\right)$. From these samples, $0.3 \mathrm{ml}$ portions were injected in alkaline $(\mathrm{pH} 9)$ anaerobic media with $1 \% \mathrm{NaCl}$; on alkaline $(\mathrm{pH} 9)$ anaerobic media in $3 \% \mathrm{NaCl}$, and marine anaerobic media with $\mathrm{pH} 7$ and $3 \% \mathrm{NaCl}$. All tubes were incubated at $3{ }^{\circ} \mathrm{C}$ for 2 weeks. The enrichment cultures were obtained in Hungate tubes containing medium with $\mathrm{pH} 7$ and $3 \% \mathrm{NaCl}$ and $\mathrm{pH} 9$ and $1 \% \mathrm{NaCl}$. The tube with $\mathrm{pH} 9$ and $3 \% \mathrm{NaCl}$ did not exhibit any growth. 


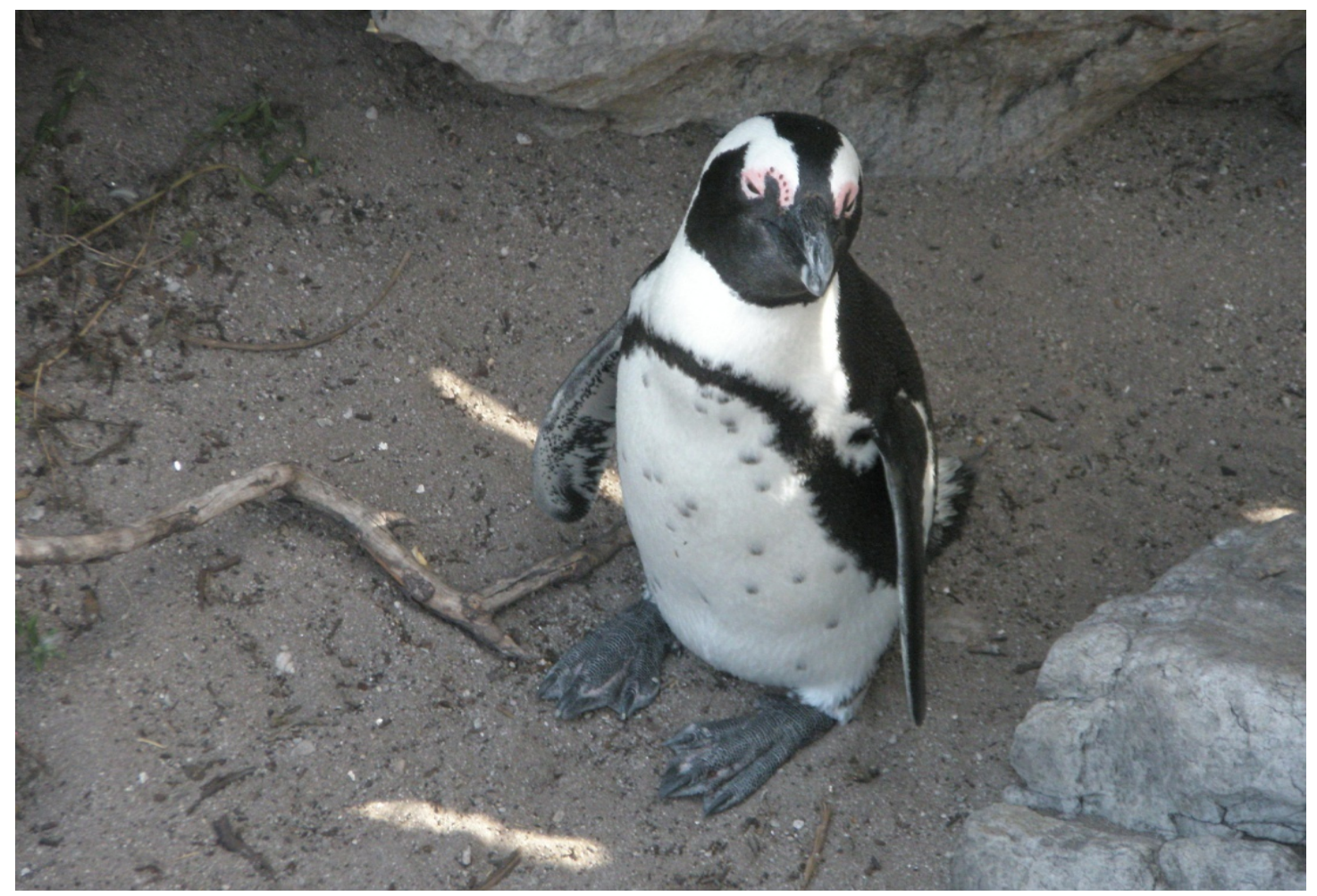

a.

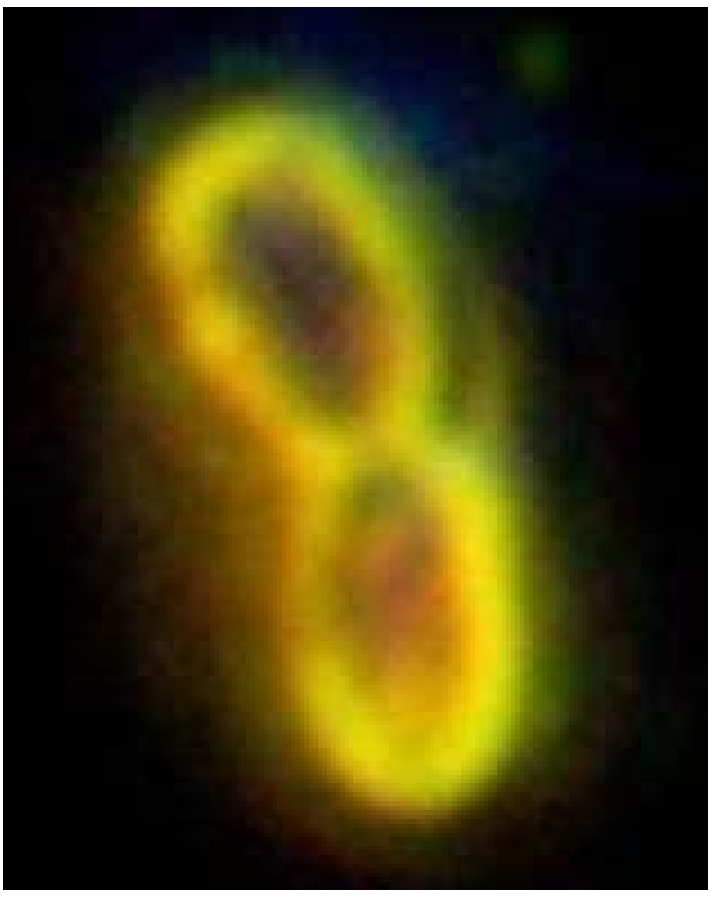

b.

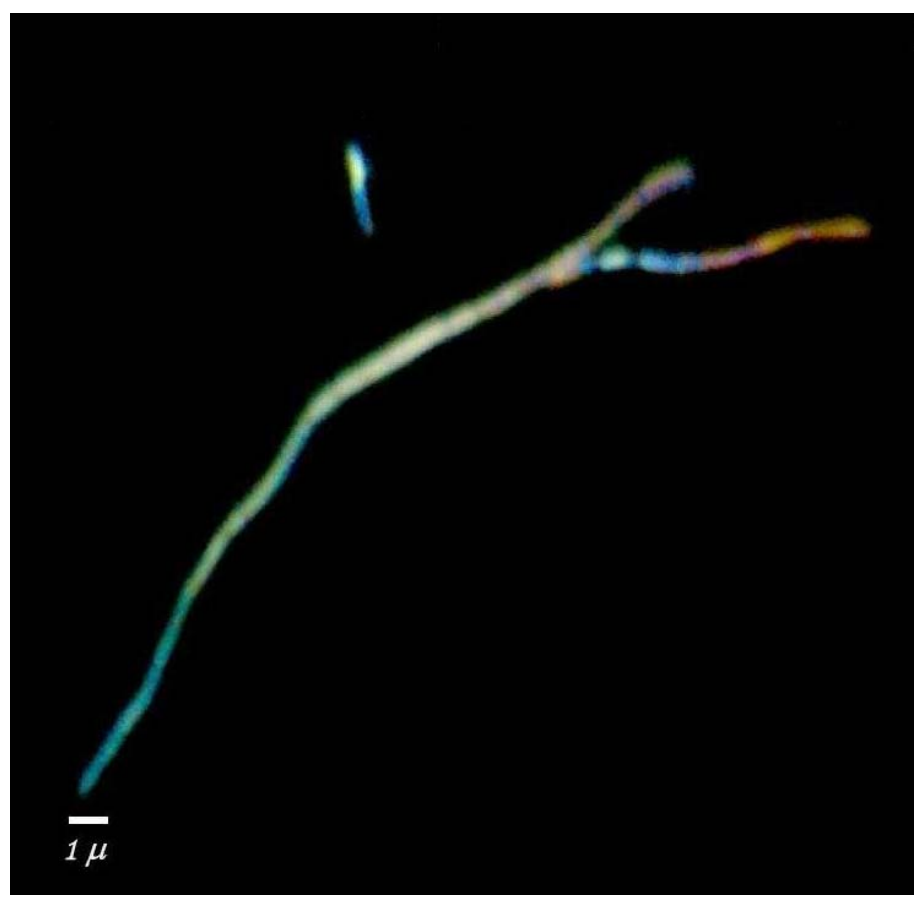

c.

Fig. 11.a. African penguins at Stony Point, Betty's Bay, South Africa. b. Cell morphology of non spore-forming strain ARHSd-7G; dividing vibrions are shown. Sizes of cells are $0.4 \mathrm{x} 1.2-1.5 \mu \mathrm{m}$. Cells are motile by polar flagella (not shown). Cells are Gram variable, anaerobic and catalase negative. c. Dark-field microscopy of strain ARHSd-9G shows specific interference coloration effect caused by material in cell walls. 
Strain ARHSd-7G was isolated on marine medium with $D$-glucose as a substrate. Cells were motile vibrions with sizes $0.6 \mathrm{x}$ 1.2-1.5 $\mu \mathrm{m}$ (Fig. 11b). Isolation of colonies was performed by "roll-tubes" method with $3 \%$ agar medium at $3{ }^{\circ} \mathrm{C}$. Strain ARHSd-7G had optimum of growth at $3 \% \mathrm{NaCl}$ and did not grow without $\mathrm{NaCl}$ or at $0.1 \% \mathrm{NaCl}$. The minimum of growth was at $0.5 \% \mathrm{NaCl}$. Strain ARHSd$7 \mathrm{G}$ was determined as highly halotolerant microorganisms, since its maximum of growth was at $24 \%$ $\mathrm{NaCl}$ with long lag-phase around three weeks. No growth was observed at $24.5 \% \mathrm{NaCl}$. Growth occurred within the $\mathrm{pH}$ range between 5.2 and 10.0, and was optimum at $\mathrm{pH}$ 8.9. No growth was observed at $\mathrm{pH} 5.0$ and 10.5 .

The range of temperature for growth of the new isolate was $3-40{ }^{\circ} \mathrm{C}$, with optimum for growth at 30 ${ }^{\circ} \mathrm{C}$. No growth was observed at 0 and $45{ }^{\circ} \mathrm{C}$. Strain ARHSd-7G was able to use as substrates some sugars and several proteolysis products, but the cultures grown on the proteolysis products was comparatively unstable: lysis of cells occurred much faster than with sugars. It grew on: maltose, $D$ glucose, $D$-fructose, sucrose, $D$-trehalose, $D$-ribose, $D$-mannitol, $D$-cellobiose, peptone, yeast extract, casamino acids, triethylamine, and pyruvate. No growth was observed on: $D$-arabinose, $L$-arabinose, $D$ mannose, lactose, starch, trimethylamine, betaine, formate, acetate, lactate, propionate, butyrate, citrate, methanol, ethanol, glycerol, and acetone. The new isolate had strictly fermentative metabolism: any acceptors of electrons $\left(\mathrm{Fe}^{3+}, \mathrm{NO}_{3}{ }^{2-}, \mathrm{SO}_{4}{ }^{2-}, \mathrm{SO}_{3}{ }^{2-}, \mathrm{S}^{\mathrm{o}}, \mathrm{S}_{2} \mathrm{O}_{4}{ }^{2-}\right)$ added to the medium did not stimulate growth. Strain ARHSd-7G was unable to reduce sulfur compounds to the $\mathrm{H}_{2} \mathrm{~S}$.

Preliminary phylogenetic analysis data showed that strain ARHSd-7G belongs to the genus Salinivibrio and had the highest similarity $(99.1 \%)$ with S. costicola. DNA-DNA hybridization analysis will be conducted to finalize the taxonomic position of this new isolate.

Strain ARHSd-9G was obtained from enrichment culture grown on alkaline medium with pH 9 and $1 \%$ $\mathrm{NaCl}$ on $D$-glucose as a substrate. Pure culture was received from $8^{\text {th }}$ dilution on "roll-tubes" with $3 \%$ agar medium. The cell morphology as is shown (Fig. 11c.) exhibits elongated straight or slightly curved rods. Cells are motile with peretrichous flagella. The strain is spore-forming and the round spores are located terminally. Sizes of cells are 0.4 x 3-5 $\mu \mathrm{m}$. Strain ARHSd-9G is strictly anaerobic , catalase negative and grows between 3 and $22{ }^{\circ} \mathrm{C}$.

\subsubsection{Microbial Extremophiles from the Schirmacher Oasis, Antarctica}

The Schirmacher Oasis of central Dronning Maud Land, Antarctica is $3 \mathrm{~km}$ wide, $20 \mathrm{~km}$ long and contains over 150 lakes. Some of the lakes are perennially ice-covered while others show open water in mid-summer. The Russian Antarctic Station Novolazarevskaya and the Indian Station Maitri are located in the Schirmacher Oasis. The 2008 International Tawani Schirmacher Oasis/Lake Untersee Expeditions were designated as official Russian Antarctic Expeditions. The team was very grateful to have been granted permission to utilize the facilities of the Novolazarevskaya Station. Numerous samples were obtained from Lakes Glubokoye, Lake Stantionoye and the nearby Ice Cave. Samples were also collected from Lake Podprudnoye and Lake Priyadarshini . The Indian Antarctic Station Maitri is situated on Lake Priyadarshini, which is the largest lake in the Schirmacher Oasis.

\subsubsection{Bacteria from Lake Zub (Lake Priyadarshini)}

A living sample of green moss with rhizosphere surrounded by soil was collected from the shore of Lake Zub (also known as Lake Priyadarshini) and returned to NASA/NSSTC in frozen state. This 
sample gave growth to a rich enrichment culture that lead to the isolation of two anaerobic psychrotolerant strains LZ-22G and LZV-3P.

Strain LZ-22G grew exclusively on sugars, on neutral medium with $\mathrm{pH} 7$, and did not require $\mathrm{NaCl}$ for growth. The range of $\mathrm{NaCl}$ concentration for growth was $0-3 \%(\mathrm{w} / \mathrm{v})$ and the optimum of growth was at $0 \% \mathrm{NaCl}$. The new isolate grew between 3 and $35{ }^{\circ} \mathrm{C}$, no growth was observed at $40{ }^{\circ} \mathrm{C}$. After freezing and thawing the strain was still alive. The $\mathrm{pH}$ range for growth of strain LZ-22G was 4.5-9.0 and the optimum growth was at $\mathrm{pH}$ 9.0. Growth was significantly stimulated by yeast extract. This strain is obligately anaerobic and catalase negative. The morphology of the cells had distinguishing characteristics: the cells were comparatively large ( $1 \mu \mathrm{m}$ diameter by $10-15 \mu \mathrm{m}$ length $)$ and the ends of cells were rounded. The cells exhibited gliding motility (Fig. 12.a).

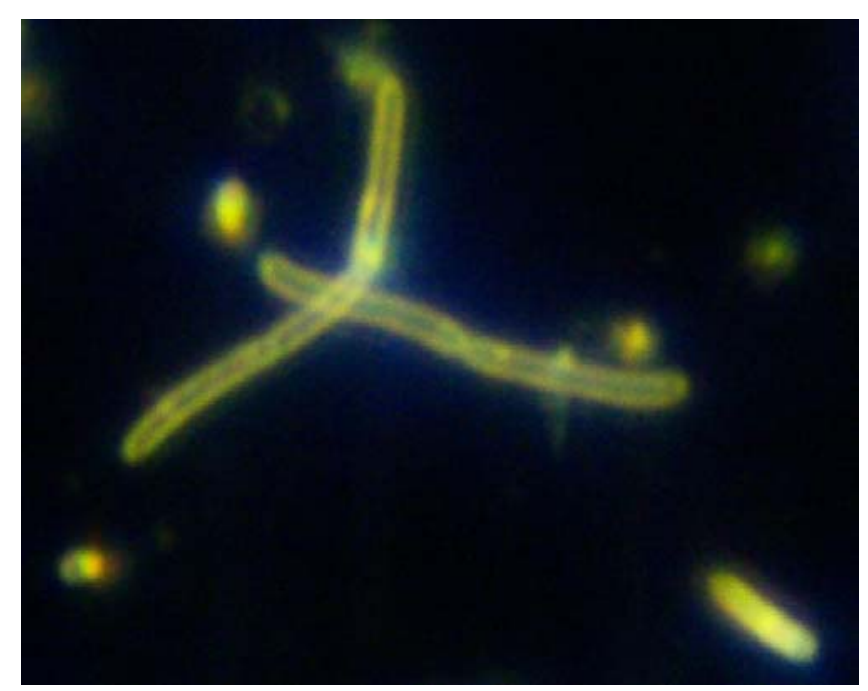

a.

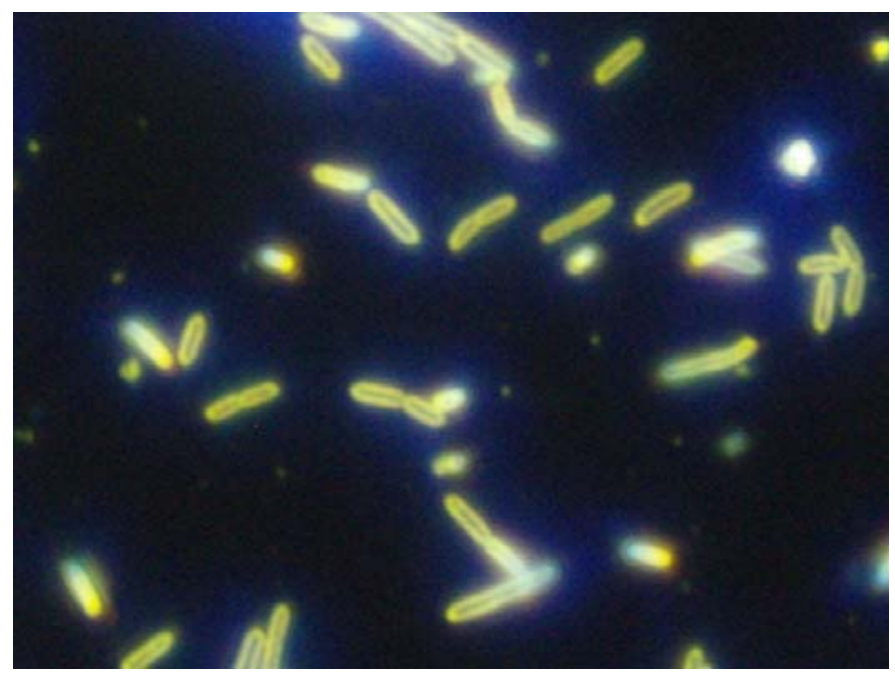

b.

Fig. 12.a. Cell morphology of strain LZ-22G growing on $D$-glucose at $3{ }^{\circ} \mathrm{C}$. Cells are motile by peretrichous flagella and are spore-forming (oval spores are located sub-terminally); b. Proteolytic vibrion cells of strain LZV-7P from frozen sample of green moss with soil around rhizosphere collected on shore of Lake Priyadarshini (Maitri station) Antarctica.

Isolation of colonies of strain LZ-22G was done by serial dilution and "roll-tube" methods. Colonies grown on 3\% agar medium had the following characteristics: Light cream color, round shape of concave lens middle of colonies had denser consistency. Colonies were smooth and shiny with diameter 0.5-4 mm; and the older colonies were transparent and surrounded by a shiny circle.

Strain LZ-22G grew on the following compounds: yeast extract, $D$-glucose, $D$-fructose, maltose, sucrose, $D$-trehalose, $D$-cellobiose, $D$-ribose, $D$-cellobiose, lactose, chitin, pectin, and starch. The best growth was observed on lactose. No growth was observed on: formate, acetate, pyruvate, lactate, propionate, butyrate, citrate, oxalate, methanol, ethanol, glycerol, acetone, betaine, trimethylamine, triethylamine, peptone, casamino acids, $D$-mannose, and $D$-arabinose.

Strain LZV-3P was also isolated from the same sample. Cells of this strain had vibrion shape and also had large sizes: $0.8 \mu \mathrm{m}$ in diameter and 3-5 $\mu \mathrm{m}$ in length (Fig. 12.b). The cells were motile and sporeforming. Strain LZV-3P had proteolytic fermenting metabolism, and grew exclusively on proteolysis products (peptone, yeast extract, casamino acids). Sugars did not support the growth of the new isolate. The culture had a specific strong smell of decomposing proteins (not hydrogen sulfide, but decaying 
meat). This strain grew between 3 and $22{ }^{\circ} \mathrm{C}$. The cells were catalase negative and strictly anaerobic and the $\mathrm{pH}$ for growth was neutral 7.0-7.5. The range of salinity for growth was $0.5-3 \% \mathrm{NaCl}$.

\subsubsection{Bacteria from Ice Sculptures near Lake Podprudnoye}

In the vicinity of Lake Podprudnoye (also known as Proglacial Lake 21), the transport vehicle encountered a large field of "ice sculptures" formed by the summer melt and wind erosion processes (Fig. 13). These "ice sculptures" contained a large number of entrained dark rocks and dust grains. Sunlight penetrates the ice and causes localized melting resulting in the formation of liquid water films around each of these trapped rocks. These water films provide an ideal environment for the growth of photoautotrophic cyanobacteria, bacteria, diatoms and other algae as well as organotrophic bacteria.

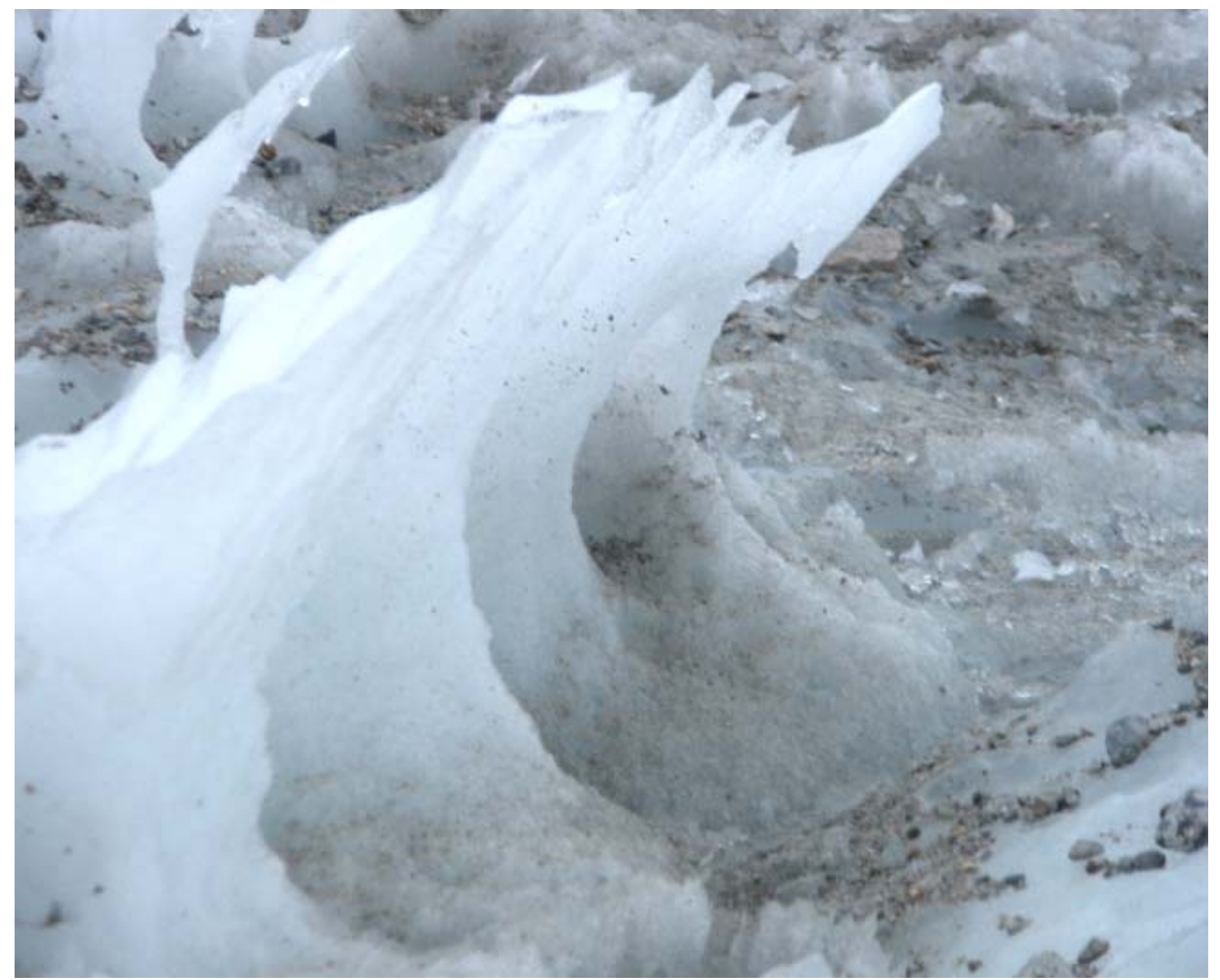

Fig. 13. "Ice sculpture" near Lake Podprudnoye in Schirmacher Oasis, Antarctica.

Strain ISLP-3 (Fig. 14) was isolated from the ice sculpture shown in Fig. 13. The frozen sample was slowly melted in a sterile flask under a pure nitrogen atmosphere. The melted liquid $(0.5 \mathrm{ml})$ was injected into a Hungate tube with anaerobic medium and incubated at $3{ }^{\circ} \mathrm{C}$ for $2-3$ weeks. The cell morphology of strain ISLP-3 had irregular shape of spore-forming vibrions with partially swollen 
sporangia and pointed ends. Cells occurred in pairs and were slightly angled. Sometimes Y-shape cells were observed. The cells have sizes of $0.5 \times 1.2-3 \mu \mathrm{m}$. The colonies of strain ISLP-3 grown on $3 \%$ agar medium had a circular concave shape with a diameter of 1-3 $\mathrm{mm}$, and the young colonies were smooth and glossy. The aged colonies had a brownish tint, opaque color and were not glossy. Strain ISLP-3 was catalase negative and obligately anaerobic microorganism. This strain is psychrotolerant and grows at 0 to $40{ }^{\circ} \mathrm{C}$. No growth was observed at $45{ }^{\circ} \mathrm{C}$. At $0{ }^{\circ} \mathrm{C}$ spore formation was not observed and the cells did not excrete the mucopolysaccharide capsules. Strain ISLP-3 does not require $\mathrm{NaCl}$ in medium and has optimum of growth at $0.1 \% \mathrm{NaCl}$. The range of $\mathrm{NaCl}$ for growth is $0-1 \%(\mathrm{w} / \mathrm{v})$. The range of $\mathrm{pH}$ for growth occurs between 6.2 and 9.8, with optimum at 8.5. This strain was able to grow on following compounds: triethylamine, chitin, $\mathrm{N}$-acetylglucosamine, urea, $D$ - glucose, $D$-arabinose, $D$-trehalose, maltose, sucrose, $D$-ribose, $D$-mannose, lactose, starch, and $D$-cellobiose. The best growth was observed on $D$-cellobiose. $D$-cellobiose. Growth was absent on following substrates: formate, acetate, pyruvate, lactate, propionate, butyrate, citrate, oxalate, methanol, ethanol, glycerol, D-mannitol, acetone, betaine, trimethylamine, peptone, yeast extract, casamino acids, pectin, and $D$-fructose.

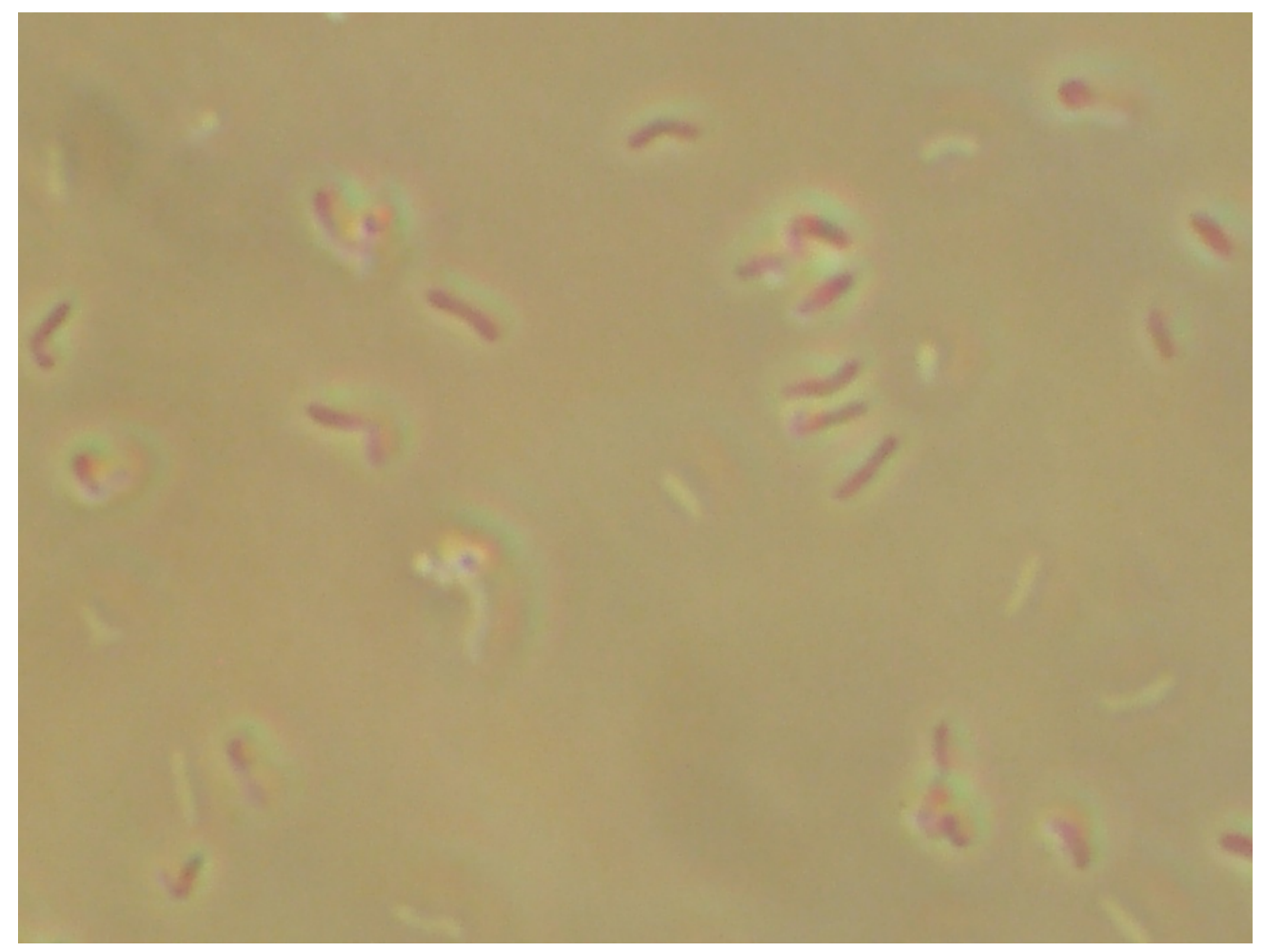

Fig. 14. Cells of strain ISLP-3 have baseball shape and irregular space configurations due to tendency for cells to clump with excreted mucopolysaccharide.

\subsection{Microbial Extremophiles from Lake Untersee}

Lake Untersee is a perennially ice-covered, ultra-oligotrophic, lake in the Otto-von-Gruber-Gebirge (Gruber Mountains) of central Dronning Maud Land. It is $563 \mathrm{~m}$ above sea level and has a surface area of $11.4 \mathrm{~km}^{2}$. It is the largest freshwater lake in east Antarctica. It is the only known highly alkaline lake on Earth that is permanently cold and constantly covered with a glacial ice sheet. It has a low mineralized aquatic system with $\mathrm{pH} \mathrm{10,} \mathrm{so} \mathrm{it} \mathrm{must} \mathrm{have} \mathrm{an} \mathrm{unusual} \mathrm{stable} \mathrm{buffer} \mathrm{system} \mathrm{that} \mathrm{has} \mathrm{not}$ previously been described.. This buffer system, as well as the microbial communities that may have adapted to live in it, needs detailed investigation. This lake has extreme physico-chemical stratification with dramatic changes in $\mathrm{pH}$, sulfides, oxygen content, and temperature as a function of depth in the 
water column as well as the highest methane concentration of any natural ecosystem on Earth (Wand et al. 2006). Although the previous physico-chemical data suggested that the Lake Untersee methane was biological in origin, the prior researchers had not conducted a detailed study of the microbiology of this cold hyper-alkaline system.

While considerable work has been done on extremophiles of the McMurdo Dry Valleys, little is known about microbial ecosystems of the Schirmacher Oasis and Lake Untersee. Studies of the cyanobacteria and algal species diversity of streams in the Oasis have been conducted (Gupta et al. 2006) and a novel obligately anaerobic proteolytic bacterium Clostridium schirmacherense was isolated from lake sediments (Alam et al. 2006). A survey of microorganisms and microbial communities that may survive in the cold, hyperalkaline environment of Lake Untersee has never been carried out.

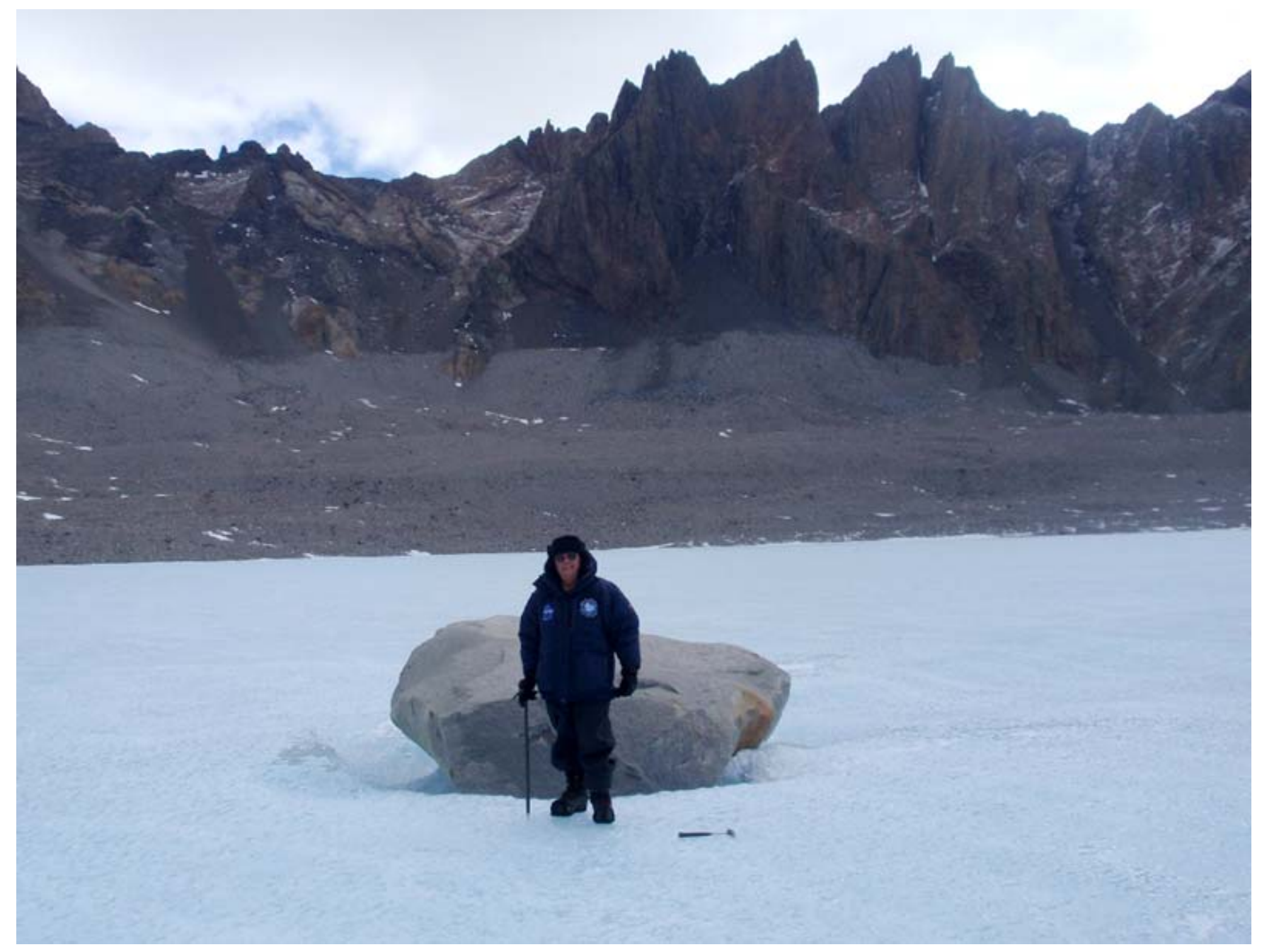

Fig. 15. "Floating Boulder" on the ice sheet that covers Lake Untersee.

Previous expeditions to Lake Untersee have conducted detailed investigations of the water chemistry. Wand et al. (2006) found that the $\mathrm{pH}$ was extremely high (mean $11.34 \pm 0.12$ ) in the near freezing water $\left(\mathrm{T} 0.8{ }^{\circ} \mathrm{C}\right.$ ) immediately beneath a $2 \mathrm{~m}$ thick ice-cover. The $\mathrm{pH}$ remains high and remarkably uniform between a depth of $3 \mathrm{~m}$ and $72 \mathrm{~m}$ before dropping dramatically from $>10$ at $72 \mathrm{~m}$ to 7.6 at $75 \mathrm{~m}$. These studies suggest the lake contains the two disparate environments characteristic of inland soda lakes: an upper layer that is most likely dominated cyanobacteria and other oxygen generating by phototrophs and a lower, anoxic sediment and water column producing high levels of methane that probably are the 
result of a relict community of bacteria and archaea. The perennially ice-covered hyper-alkaliphilic Lake Untersee in central Dronning Maud Land, East Antarctica was the primary target of the Expedition carried out in November-December, 2008. Wand et al. (1997) has previously provided data on the physico-chemical stratification in Lake Untersee. Wand and Perlt (1999) described the "floating boulders" that ride across Lake Untersee on the on the Anuchin Glacier ice sheet. During the 2008 Expedition, Dale Andersen and Chris McKay obtained new GPS data on the current positions of these "floating boulders" for comparison with Wand's data. One of the "floating boulders is show in Fig. 15.

\subsubsection{Psychrophilic and Psychrotolerant Anaerobes from Lake Untersee}

Lake Untersee was the source of isolation for several novel psychrophilic and psychrotolerant anaerobes. Two saccharolytic and one proteolytic anaerobic bacterial strains growing at $5{ }^{\circ} \mathrm{C}$ were isolated and purified. Strain UDS7-G was isolated from a sediment sample taken from the deep anoxic trough. This strain grows on anaerobic medium with $\mathrm{pH} 7,0.5 \% \mathrm{NaCl}$, and $D$-glucose. The cell morphology showed straight rods with pointed ends and the sizes of the cells were 0.7 x 2-3 $\mu \mathrm{m}$ (Fig. 16.a). This bacterium is motile and spore-forming and grows at $3-22{ }^{\circ} \mathrm{C}$.

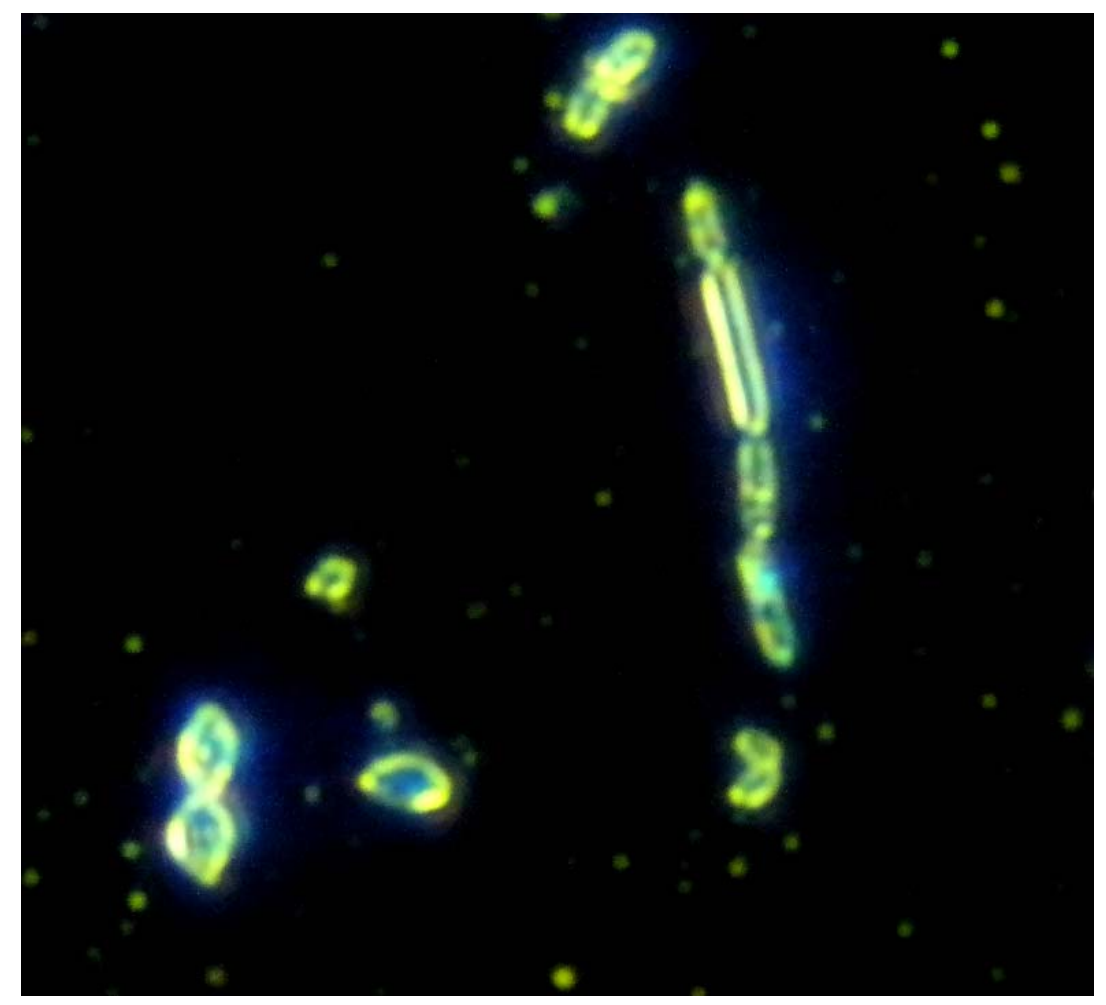

a.

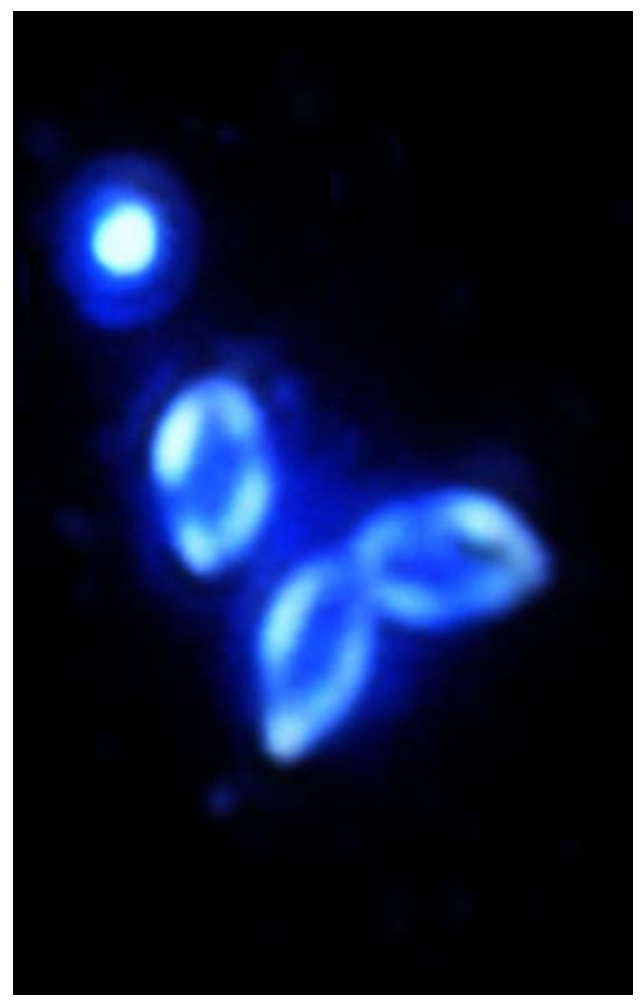

b.

Fig. 16.a. Strain UDS_7G and b. strain UL7-96mG from the Deep Anoxic Trough sediment sample of Lake Untersee.

Another sugarlytic strain UL7-96mG was isolated from $96 \mathrm{~m}$ deep water sample of Lake Untersee. It had similar morphology, and the only difference at the current stage of investigation is its growth rate; strain UL7-96mG grows significantly faster than strain UDS7-G (Fig. 16.b.). Genetic and physiological tests now underway will provide information about the identity of these two strains.

The proteolytic anaerobic bacterium, strain LU-96m7P, was also isolated from $96 \mathrm{~m}$ deep water sample of Untersee Lake on medium with $\mathrm{pH} 7,0.5 \% \mathrm{NaCl}$, and peptone as a substrate. The morphology of 
this strain shows rod-shaped motile and spore-forming cells with sizes $0.6 \times 3-5 \mu \mathrm{m}$. The strain has truly psychrophilic physiology: it grows rapidly at $3-5{ }^{\circ} \mathrm{C}$ and does not grow at $22^{\circ} \mathrm{C}$.

Strain A4P-85m was isolated on anaerobic medium with $\mathrm{pH} 3.5$ and peptone $3 \mathrm{~g} \mathrm{l}^{-1}$. The unusual "ZigZag" morphology of this strain is similar to strain LL-8 from a Patriot Hills sample obtained during the Antarctica 2000 Expedition (Hoover and Pikuta, 2004). The growth rate of this strain (Fig. 17) was much higher than the LL-8 strain with similar morphology (Fig. 10) obtained on that expedition.
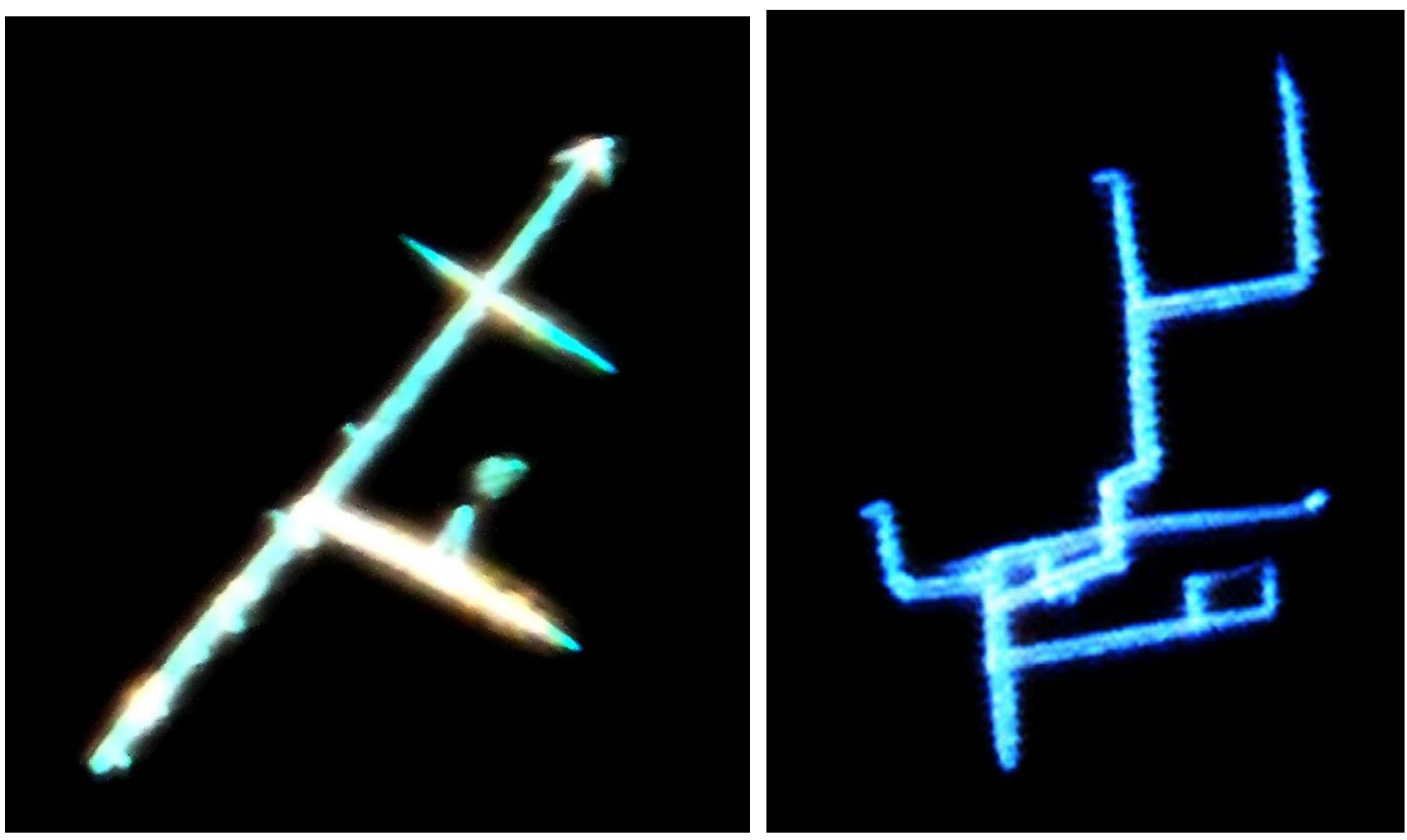

Fig. 17. Strain A4P-85m was isolated on anaerobic medium with $\mathrm{pH} 3.5$ and peptone.
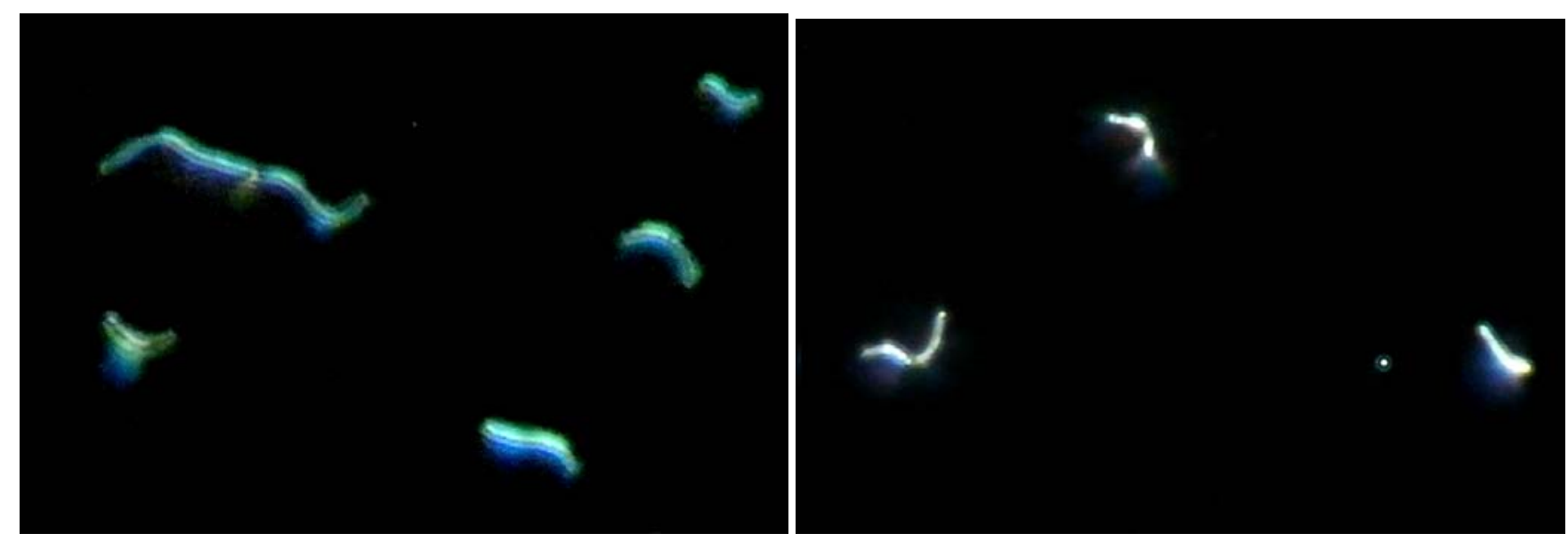

a.

b.

Fig. 18. Anaerobic cultures from Lake Untersee, Antarctica: Psychrophilic homoacetogenic bacteria a. strain A7AC-96m and b. strain A7AC-DS7 growing on $\mathrm{H}_{2}+\mathrm{CO}_{2}$ at $5{ }^{\circ} \mathrm{C}$. 
Two homoacetogenic strains A7AC-96m and A7AC-DS7 were obtained from Lake Untersee water samples at $96 \mathrm{~m}$ depth (Fig. 18.a) and from the deep anoxic trough sediment sample (Fig. 18.b) respectively. Both of these bacteria are motile vibrions that grow at $5{ }^{\circ} \mathrm{C}$ and $\mathrm{pH}$ 7. Cell sizes 0.6$0.7 \times 2.0-4.0 \mu \mathrm{m}$. Slow growth (during 3 weeks) was observed at $14{ }^{\circ} \mathrm{C}$, which was the maximum temperature limit for growth. This indicates the truly psychrophilic nature of these strains. Both strains grew litho-autotrophically (during 2 days after inoculation) on $\mathrm{H}_{2}+\mathrm{CO}_{2}$ as the only source for energy and carbon.

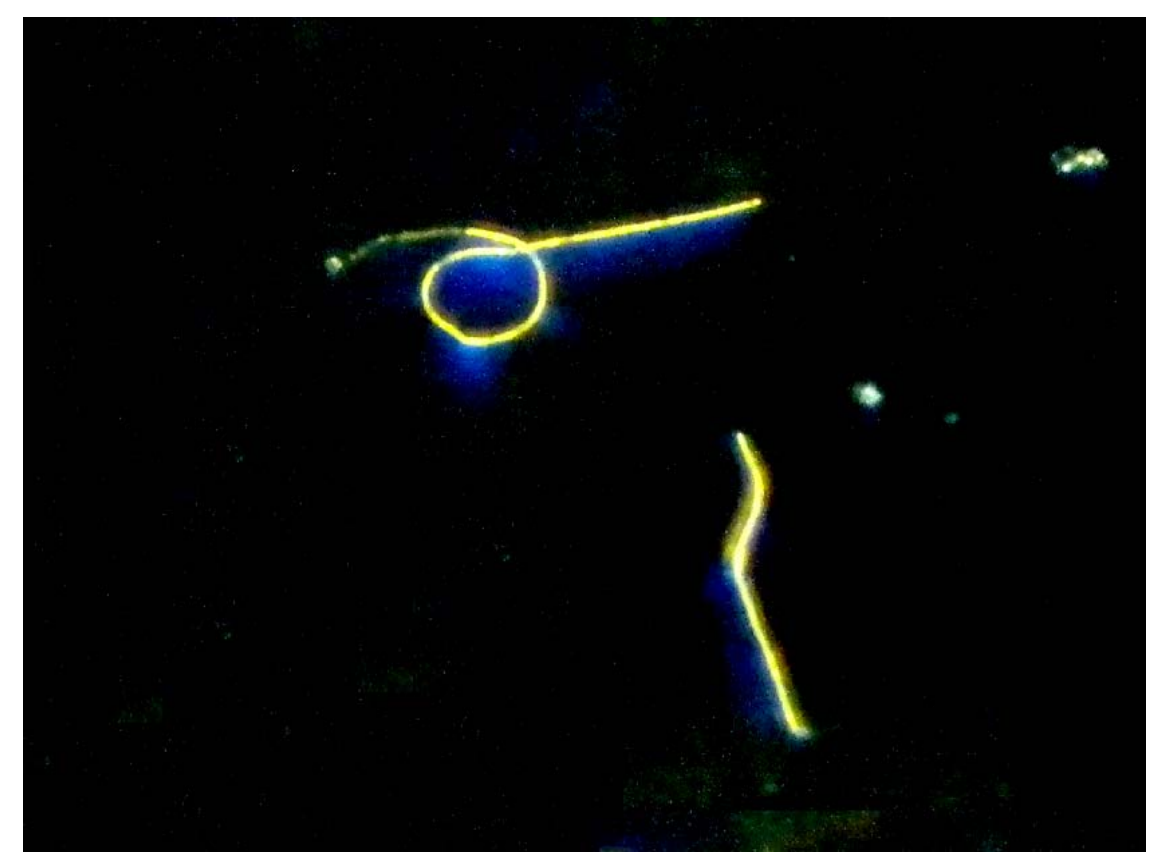

a.

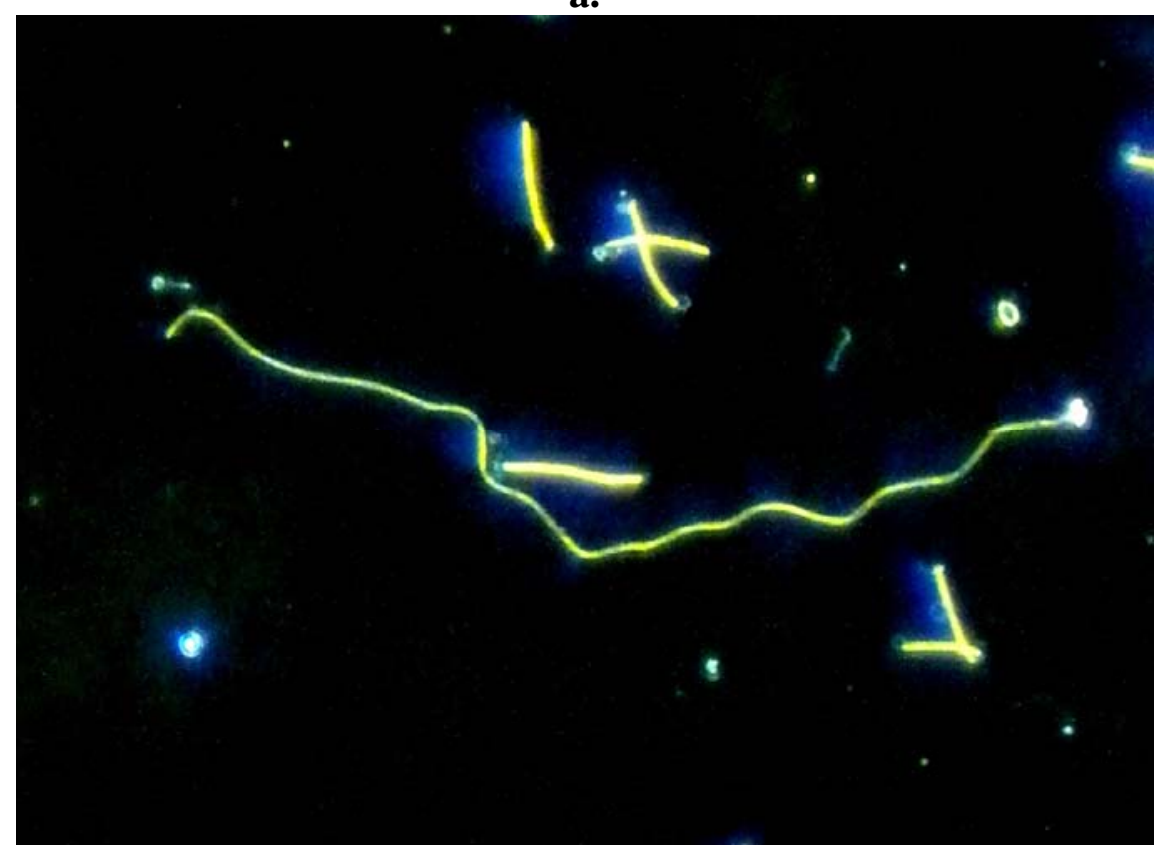

b.

Fig. 19.a,b Anaerobic cultures from Lake Untersee, Antarctica: Psychrophilic proteolytic strain AP7-90 growing at $\mathrm{pH} 7$ with peptone. 
Another proteolytic strain AP7-90 was obtained from a sample of the water at $90 \mathrm{~m}$ depth at the Lake Untersee Deep Anoxic Trough on anaerobic medium at $\mathrm{pH} 7$ with peptone. The morphology of the cells is long thin or curved hair-like rods (Fig. 19a) (sizes $0.3-0.4 \times 10-15 \mu \mathrm{m}$ ) with laterally located spores (Fig. 19.b).

\subsection{Microorganisms in-situ in Ice-Bubbles}

One of the most surprising observations made during the 2008 Tawani Expeditions to the Schirmacher Oasis and Lake Untersee in Antarctica was the great abundance of viable bacteria in the ice bubbles. Spectacular "ice-bubble" systems were observed throughout the upper layers of the ice sheet covering Lake Glubokoye in the Schirmacher Oasis in November, 2008 (Fig. 20).

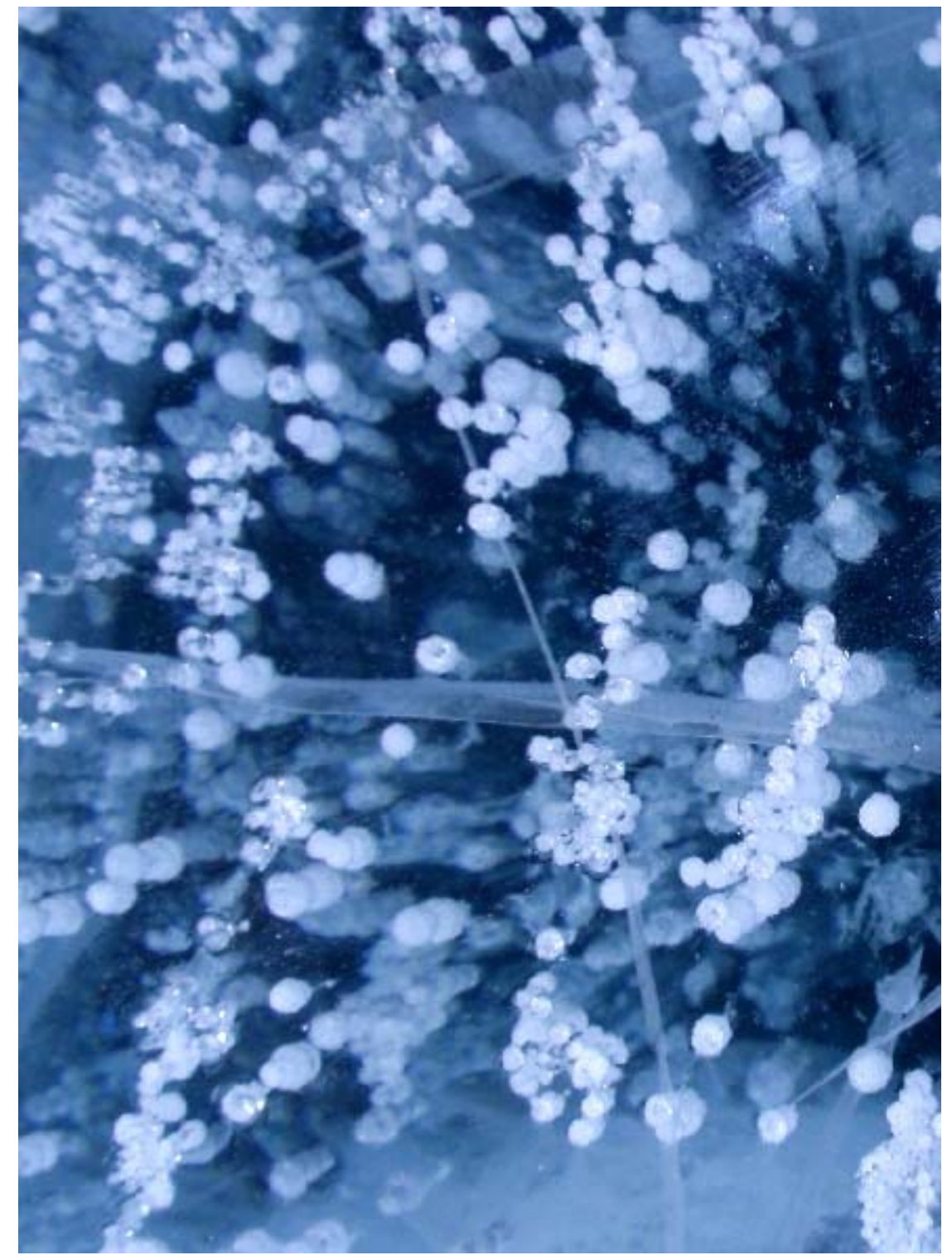

Fig. 20. Ice-bubble assemblages containing entrained rocks and living bacteria near surface of Lake Glubokoye, Antarctica.

Similar ice bubble assemblages were also found in the Anuchin Glacier and the ice sheet over Lake Untersee. Even though the ice-bubble samples appeared completely transparent and clear, as soon as 
the samples were thawed, large numbers of morphologically diverse, motile bacterial cells were observed. Their motility was documented in the field using high resolution dark field video photomicroscopy methods. We had previously observed motile bacteria in ice-bubbles found in the blue ice at the Patriot Hills and the Thiel Mountains during the Antarctica 2000 Expedition and during field expeditions to Matanuska Glacier of Alaska. The ice-bubbles absorb solar radiation and melt the ice forming thin films or pockets of liquid water trapped within the interior of the ice. Bacteria, cyanobacteria, diatoms and other microorganisms grow within these bubbles and produce metabolic end products that generate micro-niches within the ice (Hoover and Gilichinsky, 2001; Bargagli, 2005). Unfortunately, this interesting ecosystem has received very little attention by microbiologists.

The pioneering investigations of viable and entrapped microorganisms in the deep ice sheet above Lake Vostok, Antarctica were carried out by Sabit S. Abyzov of the Institute of Microbiology of the Russian Academy of Sciences. The research has shown that viable microorganisms can remain alive while trapped deep within the Antarctic Ice Sheet (Abyzov, 1993; Karl et al., 1999; Siegert et al., 2001). Phylogenetic analysis of 16s rRNA sequences and bacterial isolates and amplicons obtained from melted ancient ( $500 \mathrm{kyr})$ glacial ice samples and accretion ice above Lake Vostok has yielded 6 different bacterial lines of $\alpha$-, $\beta$-, and $\gamma$-proteobacteria (Christner, 2002). Recent reviews of the studies of the microorganisms of the ice layers above Lake Vostok have been provided (Abyzov, et al., 2005, 2006 Bell et al., 2005). The microorganisms cultivated from these ancient glacial ice samples were primarily psychrotolerant mesophiles, with the ability to grow at $4{ }^{\circ} \mathrm{C}$ but optimal growth occurred above $20^{\circ} \mathrm{C}$. However, Bulat et al., (2004) have reported the detection of the signatures of thermophilic microorganisms in the ice above Lake Vostok.

The astonishing ability of microorganisms to remain alive for long periods of time while trapped in deep layers of the Antarctic Ice Sheet and to grow actively within the ice bubbles of great significance to Astrobiology. Thick ice sheets can provide protection from hard vacuum and the radiation environment of space and create localized conditions suitable for the needs of the specific microorganisms. Consequently, the polar ice caps and permafrost of Mars, the icy cores of comets, and the crustal layers of the icy moons of Jupiter and Saturn may comprise appropriate environments for the growth of psychrophilic and psychrotolerant species such as are able to inhabit the polar environments, glaciers and ice sheets of planet Earth.

\section{RELEVANCE OF POLAR MICROBIAL EXTREMOPHILES TO ASTROBIOLOGY}

Several of the observations made during these expeditions may have relevance to Astrobiology. During the 2008 Lake Untersee Expedition, Dale Anderson and Chris McKay triggered an "ice geyser" when their drill entered a localized pockets of high pressure air in the upper layer of the Anuchin Glacier ice sheet covering the surface of Lake Untersee. This interesting phenomenon may have relevance to understanding the nature of the recently discovered "ice geysers" that erupt from the cracks in "tiger stripe" area of Saturn's moon Enceladus. Ice Bubbles were found throughout the surface of Lake Untersee and Lake Glubokoye in the Schirmacher Oasis. Motile bacteria were observed by high resolution dark field microscopy at the moment of melting of these "ice bubble" samples. The presence of viable bacteria frozen in the ice of the Anuchin Glacier at Lake Untersee, suggests that it may not be necessary to drill through the thick icy crusts to search for life in the seas of the frozen moons of Jupiter and Saturn as viable cells might be cryopreseved in the upper layers of the ice crust.

While it is generally accepted that life on Earth had an endogenous origin, biomarkers in some of the most ancient rocks on Earth suggest that the endogenous origin hypothesis cannot be logically 
excluded. The study of psychrophiles may provide a means of differentiating these two models. As we previously poined out (Pikuta et al., 2007), psychrophily among biological forms would have to have developed after a significant temperature drop on the Earth's surface. Hence, the phenotypic features of life should be reflected at the genotype level with all adaptation changes encoded during the later period of the Earth's evolution - after the appearance of constant polar ice caps. If this model is correct, then cold-shock proteins and the other cold-adaptive structures and mechanisms for cells should be encoded on the level of plasmids and surface genes, which are more recent and unstable genetic units that are more easily modified. However, if truly psychrophilic microorganisms originated elsewhere in the Cosmos (where the evolution of life experienced different scenarios) and these microorganisms were delivered to Earth by comets or meteorites, then the phenotype of these microorganisms with psychrophilic features should be tightly connected with the most general life processes and structures and located deeply in conservative and stable genetic units. As a result, such microorganisms would appear on separate phylogenetic lineages of genera, families, and higher taxa levels. While both types of psychrophilic microorganisms may currently coexist in Nature, studies of isolation of plasmids, expression of genes, etc. may help differentiate between these two hypotheses for the origin of life on Earth.

\section{SUMMARY}

The microbial extremophiles that inhabit the polar regions of our planet are of tremendous significance. The psychrophilic and psychrotolerant microorganisms, which inhabit all of the cold environments on Earth have important applications to Bioremediation, Medicine, Pharmaceuticals, and many other areas of Biotechnology. Until recently, most of the research on polar microorganisms was confined to studies of polar diatoms, yeast, fungi and cyanobacteria. However, within the past three decades, extensive studies have been conducted to understand the bacteria and archaea that inhabit the Arctic and Antarctic sea-ice, glaciers, ice sheets, permafrost and the cryptoendolithic, cryoconite and ice-bubble environments. These investigations have resulted in the discovery of many new genera and species of anaerobic and aerobic microbial extremophiles. Exotic enzymes, cold-shock proteins and pigments produced by some of the extremophiles from polar environments have the potential to be of great benefit to Mankind. Knowledge about microbial life in the polar regions is crucial to understanding the limitations and biodiversity of life on Earth and may provide valuable clues to the Origin of Life on Earth. The discovery of viable microorganisms in ancient ice from the Fox Tunnel, Alaska and the deep Vostok Ice has shown that microorganisms can remain alive while cryopreserved in ancient ice. The psychrophilic lithoautotrophic homoacetogen isolated from the deep anoxic trough of Lake Untersee is an ideal candidate for life that might inhabit comets or the polar caps of Mars. The spontaneous release of gas from within the Anuchin Glacier above Lake Untersee may provide clues to the ice geysers that erupt from the "tiger stripe" regions of Saturn's moon Enceladus. The methane productivity in the lower regimes of Lake Untersee may also provide insights into possible mechanisms for the recently discovered methane releases on Mars. Since most of the other water bearing bodies of our Solar system are frozen worlds, microbial extremophiles from the Polar Regions of Earth are of great importance to Astrobiology in understanding where and how to search for evidence of life elsewhere in the Cosmos. 


\section{REFERENCES}

Absil, M. C. P. and Y. van Scheppingen. 1996. Concentrations of Selected Heavy Metals in Benthic Diatoms and Sediment in the Westerschelde Estuary Bulletin of Environmental Contamination and Toxicology, 56: 1008-1015.

Abyzov, S. S. 1993. Microorganisms in Ancient Ice. Antarctic Microbiology. (e. I. Friedman, Ed.) Wiley-Liss, Inc., New York. Pp. 265-296.

Abyzov, S. S., Mitskevich, I. N., Poglazova, M. N., Barkov, N. I., Lipenkov, V. Ya., Bobin, N. E., Koudryashov, B. B., Pashkevich, V. M. and M. V. Ivanov. 2001. Microflora in the basal strata at Antarctic ice core above the Vostok lake. Adv Space Res 28: 701-706.

Abyzov, S. S., Poglazova, M. N., Mitskevich, I. N. and M. V. Ivanov. 2005. Common features of microorganisms in ancient layers of the Antarctic Ice Sheet, In J. D. Castello and S. O. Rogers (ed.), Life in ancient ice. Princeton University Press, Princeton, NJ. Pp. 240-250.

Abyzov, S. S., Poglazova, M. N., Mitskevich, I. N. and M. V. Ivanov. 2005. Common features of microorganisms in ancient layers of the Antarctic Ice Sheet, In J. D. Castello and S. O. Rogers (ed.), Life in ancient ice. Princeton University Press, Princeton, NJ. Pp. 240-250.

Abyzov, S. S., Duxbury, N. S., Bobin, N. E., Fukuchi, M., Hoover, R. B., Kanda, H., Mitskevich, I. N., Mulyukin, A. L., Naganuma, T., Poglazova, M. N. and M. V. Ivanov. 2006. Super-long anabiosis of ancient microorganisms in ice and terrestrial models for development of methods to search for life on Mars, Europa and other planetary bodies. Advances in Space Research, Space Life Sciences, 38: 1191-1197.

Adam, C, and J. Garnier-Laplace. 2003. Bioaccumulation of silver-110m, cobalt-60, cesium-137, and manganese-54 by the freshwater algae Scenedesmus obliquus and Cyclotella meneghiana and by suspended matter collected during a summer bloom event. Limnology and Oceanography, 48: 2303-2313.

Aislabie, J. M., Balks, M. R., Foght, J. M. and E. J Waterhouse. 2004. Hydrocarbon spills on Antarctic Soils: Effects and Management. Environ Sci Technol 38: 1265-1274.

Aislabie, J., Foght, J. and D. Saul. 2000. Aromatic hydrocarbon-degrading bacteria from soil near Scott Base, Antarctica. Polar Biol 23: 183-188.

Alam, S. I., Dixit, A., Reddy, G. S. N., Dube, S., Palit, M., Shivaji, S. and L. Singh. 2006. Clostridium schirmacherense sp. nov., an obligately anaerobic, proteolytic, psychrophilic bacterium isolated from lake sediment of Schirmacher Oasis, Antarctica. Int J Syst Evol Microbiol 56: 715-717.

Antić, M. P., Jovancicevic, B., Vrvić, M. M. and J. Schwarzbauer. Petroleum Pollutant Degradation by Surface Water Microorganisms. Environ Sci Pollution Res 13: 287-360.

Bakermans, C., Ayala-del-Río, H. L., Ponder, M. A., Vishnivetskaya, Gilichinsky, D., Thomashow, M. F. and J. M. Tiedje. 2006. Psychrobacter cryohalolentis sp. nov. and Psychrobacter arcticus sp. nov., isolated from Siberian permafrost. Int J Syst Evol Microbiol 56: 1285-1291. 
Bargagli, R. 2005. Antarctic Ecosystems Environmenal Contamination, Climate Change and Human Impact. Ecological Studies 175. Springer. p. 60.

Bell, R. M., Studinger, A. Tikku, and J. D. Castello. 2005. Comparative biological analyses of accretion ice from subglacial Lake Vostok, p. 251-267. In J. D. Castello and S. O. Rogers (ed.), Life in ancient ice. Princeton University Press, Princeton, NJ. Pp. 251-267.

Bej, A. K., Saul, D. and Aislabie, J. 2000. Cold-tolerant alkane-degrading Rhodococcus species from Antarctica. Polar Biol 23: 100-105.

Bowman, J. P., Brown, M. V. and D. S. Nichols. 1997. Biodiversity and ecophysiology of bacteria associated with Antarctic sea ice. Antarctic Science 9: 134-142.

Bowman, J. P., Rea, S. M., McCammon, S. A. and T. A. McMeekin. 2001. Diversity and community structure within anoxic sediment from marine salinity meromictic lakes and a coastal meromictic marine basin, Vestfold Hills, Eastern Antarctic. Environmenal Microbiology, 2: 227-237.

Brambilla, E., Hippe, H., Hagelstein, A., Tindall, B. J. and E. Stackebrandt. 2001. 16S rDNA diversity of cultured and uncultured prokaryotes of a mat sample from Lake Fryxell, McMurdo Dry Valleys, Antarctica. Extremophiles 5: 22-33.

Bräuer, S. L., Cadillo-Quiroz, H., Yashiro, E., Yavitt, J. B. and S. H. Zinder. 2006. Isolation of a novel acidiphilic methanogen from an acidic peat bog. Nature 442: 192-194.

Broady, P. A. 1981. The ecology of sublithic terrestrial aglae at the Vestfold Hills, Antarctica. British Phycological Journal 16: 231-240.

Broady, P. A. 1982. Ecology of non-marine algae at Mawson Rock, Antarctica. Nova Hedwigia 36: 209-229.

Bücker, M, Glatt, H. R., Platt, K. L., Avnir, D., Ittah, Y., Blum, J. and F. Oesch. 1979. Mutagenicity of phenanthrene and phenanthrene K-region derivatives. Mutat Res., 66: 337-348.

Bulat, S. A., Alekhina, I. A., Blot, M., Petit, J. R., Waggenbach, D., Lipenkov, V. Y., Raynaud, D. and V. V. Lukin. 2004. Thermophiles microbe signatures in Lake Vostok, Antarctica. Eos Trans. 83: B021-A09.

Burckle, L. H., Gayley, R.I., Ram, M. and J. R. Petit, 1988. Diatoms in Antarctic ice cores: Some implications for the glacial history of Antarctica. Geology 164: 326-329.

Callegan, R. P., Nobre, M. F., McTernan, P. M., Battista, J. R., Navarro-González, R., McKay, C. P., da Costa, M. S., and F. A. Rainey. 2008. Description of four novel psychrophilic, ionizing radiation-sensitive Deinococcus species from alpine environments. Int J Syst Evol Microbiol 58: 1252-1258. 
Castracane, A. F. A. 1886. Report on the Diatomaceae collected by the H. M. S. Challenger during the years 1873-76. In Reports of the Scientific Voyage of H. M. S. Challenger-Botany 2: pp. 1-178.

Cavanaugh, J. E., Nichols, P. D., Franzmann, P. D. and T. A. McMeekin 1998. Hydrocarbon degradation by Antarctic coastal bacteria. Antarctic Science 10: 386-397.

Cerniglia, C. E., Gibson, D. T. and C. Van Baalen, 1979. Algal oxidation of aromatic hydrocarbons: formation of 1-naphthol from naphthalene by Agmenellum quadruplicatum, strain PR-6. Biochem Biophys Res Commun. 88: 50-58.

Chong, S., Liu, Y., Cummins, M., Valentine, D. and D. Boone. 2002. Methanogenium marinum sp. nov., a $\mathrm{H}_{2}$-using methanogen from Skan Bay, Alaska, and kinetics of $\mathrm{H}_{2}$ utilization. Antonie van Leeuwenhoek 81: 263-270.

Christner, B. C. 2002. Detection, Recovery, Isolation and Characterization of Bacteria in Glacial Ice and Lake Vostok Accretion Ice. Ph. D. Dissertation. Ohio State University Print. Pp. 200.

Conrad, R., Bak, F., Seitz, H. J., Thebrath, B., Mayer, H. P. and H. Schulz. 1989. Hydrogen turnover by psychrophilic homoacetogenic and mesophilic methanogenic bacteria in anoxic paddy soil and lake sediment. FEMS Microbiol Ecol 62: 285-294.

Darling, C. A. and P. A. Siple. 1941. Bacteria of Antarctica. J. Bacteriol. 42: 83-98.

Dedysh, S. N., Berestovskaya, Y. Y., Vasylieva, L. V., Belova, S. E., Khmelenina, V. N., Suzina, N. E., Trotsenko Y. A., Liesack, W. and G. A. Zavarzin. 2004. Methylocella tundrae sp. nov., a methanotrophic bacterium from acidic tundra peatlands. Int J Syst Evol Microbiol 54: 151-156.

Dedysh, S. N., Liesack, W., Khmelenina, V. N., Suzina, N. E., Trotsenko, Y. A., Semrau J. D., Bares, A. M., Panikov, N. S. and J. M. Tiedje 2000. Methylocella palustris gen. nov., sp. nov., a new methane-oxidizing acidophilic bacterium from peat bogs, representing a novel subtype of serine-pathway methanotrophs. Int J Syst Evol Microbiol 50: 955-969.

D'Elia, T., Veerapaneni, R. and S. O. Rogers, 2008. Isolation of Microbes from Lake Vostok Accretion Ice, Applied and Environmental Microbiology. 4962-4965.

Douglas, M. S. V. and J. P. Smol. 1999. Freshwater diatoms as indicators of environmental change in the High Arctic. In E. F. Stoermer and J. P. Smol, Eds. The Diatoms: Applications for the Environmental and Earth Sciences. Cambridge University Press, pp. 227-244.

Dunfield, P. F., Khmelenina, V. N., Suzina, N. E., Trotsenko, Y. A. and S. N. Dedysh, 2003. Methylocella silvestris sp. nov., a novel methanotroph isolated from an acidic forest cambisol. Int J Syst Evol Microbiol 53: 1231-1239.

Duval, B., Shetty, K. and W. H. Thomas. 2000. Phenolic compounds antioxidant properties in the snow alga Chlamydomonas nivalis after exposure to UV light. J Appl Phycol 11: 559-566.

Eichler, B. and B. Schink. 1984. Oxydation of primary aliphatic alcohols by Acetobacterium carbinolicum sp. nov., a homoacetogenic anaerobe. Arch Microbiol 140: 147-152. 
Foster, J. 1887. Über eihnigh Eigenschafter leuchtender Bakterien. Centr Bakteriol Rev Parasitenk 2: 337-340.

Franzmann, P. D., Höpfl, P., Weiss, N., and B. J. Tindall. 1991. Psychrotrophic, lactic acid-producing bacteria from anoxic waters in Ace Lake, Antarctica; Carnobacterium funditum sp. nov. and Carnobacterium alterfunditum sp. nov. Arch Microbiol 156: 255-262.

Franzmann, P. D., Deprez, P. P., Burton, H. R. and J. van den Hoff. 1987. Limnology of Organic Lake, Antarctica, a meromictic lake that contains high concentrations of dimethyl sulfide. Australian Journal of Marine Freshwater Research 38: 409-417.

Franzmann, P. D., Liu, Y., Balkwill, D. L., Aldrich, H. C., Conway de Macario, E. and D. R. Boone. 1997. Methanogenium frigidum sp. nov., a psychrophilic, H2-using methanogen from Ace Lake, Antarctica. Int J Syst Bacteriol 47: 1068-1072.

Gaidos, E., Marteinsson, V., Thorsteinsson, T., Johanneson, T., Runarsson, A. R., Stefanson, A., Glazer, B., Lanoil, B., Skidmore, M., Han, S., Miller, M., Rusch, A. and W. Foo. 2008. An oligarchic microbial assemblage in the anoxic bottom waters of a volcanic subglacial lake. The ISME Journal 1-12. www.nature.com/ismej

Geittel, A., Mumann, M., Sass, H. Cypionka, H. and M. Konneke. 2008. Identity and abundance of active sulfate-reducing bacteria in deep tidal flat sediments determined by directed cultivation and CARD-FISH analysis. Env Microbiol, 10: 2645-2658.

Glatz, R. E., P. W. Lepp, B. B. Ward and C. A. Francis. Microbial diversity in the water column of permanently ice-covered Lake Bonney, Antarctica. Geobiology, 4: 53-67 (2006).

Gounot, A-M. 1991. Bacterial Life at low temperature: physiological aspects and biotechnological implications. J. Appl. Bacteriol. 71: 386-397.

Gupta, R. K., Pandey, V. D., Pandey, K. D. and D. Vyas, 2006. Algal Species Diversity of Streams of Schirmacher Oasis, Antarctica. in Glimpses of Cyanobacteria (Gupta, R. K., Kumar, M., and Paliwal, G. S., Eds.) Daya Publishing House, Delhi. pp. 231-241.

Hamilton, T.D., Craig, J.L., and P. V. Sellman. (1988). The Fox permafrost tunnel: A late Quaternary geologic record in central Alaska. Geol Soc Amer Bull 100: 948-969

Hoham, R.W. 1975. Optimum temperatures and range for the growth of snow alga. Arct. and Antarct Alp Res 7: 13-24.

Hoham, R.W. and H.U. Ling. 2000. Snow algae. The effects of chemical and physical factors on their life cycles and populations. In: J. Seckbach (ed.), Journey to Diverse Microbial Worlds. Kluwer Academic Publishers, Dordrecht, pp. 131-145.

Hoover, R. B. and Gilichinsky, D. "Significance to Astrobiology of Microorganisms in Permafrost and Ice," in Permafrost Response on Economic Development, Environmental Security and Natural Resource Potential, NATO-ARW held in NOVOSIBIRSK, SIBERIA, 12-16 Nov. 1998. (Roland Paepe, Ed.) Klewer Publishing, New York, 553-580 (2001). 
Hoover, R. B. and E. V. Pikuta. 2004. Microorganisms on comets, Europa, and the polar ice caps of Mars. SPIE, 5163: 191-201.

Hoover, R. B., Pikuta, E. V., Townsend, A., Anthony, J., Guisler, M., McDaniel, J., Bej, A. and M. Storrie-Lombardi. 2008. Microbial extremophiles from the 2008 Schirmacher Oasis Expedition: preliminary results. Proc. SPIE 7097: 70970L.

Hughes, K. A. and Bridge, P. 2009. Tolerance of Antarctic soil fungi to hydrocarbons and their potential role in soil bioremediation. (This Volume)

Huston, A. L. (2007). Biotechnological Aspects of Cold Adapted Enzymes. In: Psychrophiles: From Biodiversity to Biotechnology (Margesin, R., Schinner, F., Marx, J-C, and Gerday, E. Eds.) Springer, pp. 347-364.

Juck, D., Charles, T., Whyte, L. G., and C. W. Greer. 2000. Polyphasic microbial community analysis of peteroleum hydrocarbon-contaminated soils from two northern Canadian communities. FEMS Microbiology Ecology 33:241-249.

Karl, D. M., Bird, D. F., Björkman, K., Houlihan, T., Shackelford, R. and L. Tupas. 1999. Microorganisms in the Accreted Ice of Lake Vostok, Antarctica Science 286: 2144-2147.

Karr, E. A., Sattley, W. M., Rice, M. R., Jung, D. O., Madigan, M. T. And L. Achenbach. 2005. Diversity and distribution of sulphate-reducing bacteria in permanently frozen Lake Fryxell, McMurdo Dry Valleys, Antarctica. Appl Environ Microbiol 71: 6353-6359.

Kellogg, T. B. and D. E. Kellogg, 2002. Non-marine diatoms from the Antarctic and Subantarctic regions, distribution and updated taxonomy. In: Witkowski, A. (ed.), Diatom Monographs. Ganter Verlag, Ruggell.

Knoblauch, C., Sahm, K. and B. B. Jørgensen. 1999. Psychrophilic sulfate-reducing bacteria isolated from permanently cold Arctic marine sediments: description of Desulfofrigus oceanense gen. nov., sp. nov., Desulfofrigus fragile sp. nov., Desulfofaba gelida gen. nov., sp. nov., Desulfotalea psychrophila gen. nov., sp. nov. and Desulfotalea arctica sp. nov. Int J Syst Bacteriol 49: 1631-1643.

Kotsyurbenko, O. R., Simankova, M. V., Nozhevnikova, A. N., Zhilina, T. N., Bolotina, N. P., Lysenko, A. M. and G. A. Osipov. 1995. New species of psychrophilic acetogens: Acetobacterium bakii sp. nov., A. paludosum sp. nov., A. fimetarium sp. nov. Arch Microbiol 163: 29-34.

Kotsyurbenko, O. R., Glagolev, M. V., Nozhevnikova, A. N. and R. Conrad. 2001. Competition between homoacetogenic and methanogenic archaea for hydrogen at low temperature. FEMS Microbiol Ecol 38: 153-159.

Long, A. and T. L. Pewe. (1996), Radiocarbon Dating by High Sensitivity Liquid Scintillation Counting of Wood from the Fox Permafrost Tunnel near Fairbanks, Alaska. Permafrost and Periglacial Processes, 7: 281-285.

McClean, A. L. 1918. Bacteria of the Ice and Snow in Antarctica. Nature. 102: 35-39. 
McKenzie, R. L., Bjorn, L. O., Bais, A. and M. Iayis. 2003. Changes in biologically active ultraviolet radiation reaching the Earth's Surface. Photochem Photobiol Sci, 2: 5-15.

Milucki, J. A. and J. C. Priscu, 2007. Bacterial Diversity Associated with Blood Falls, a Subglacial Outflow from the Taylor Glacier, Antarctica. Applied and Environmental Microbiology, 73: 4029-4039. http://www.pubmedcentral.nih.gov/articlerender.fcgi?artid=1932727

Mock, T. and K. Junge, 2007. Psychrophilic Diatoms: Mechanisms for Survival in Freeze-Thaw Cycles. In Algae and Cyanobacteria in Extreme Environments (J. Seckbach, Ed.), Springer. pp. 345-364.

Montes-Hugo, M., Doney, S. C., Ducklow, H. W., Fraser, W., Martinson, D., Stammerjohn, S. E. and O. Schofield. 2009. Recent changes in phytoplankton communities associated with rapid regional climate changes along the Western Antarctic Peninsula. Science 323: 1470-1473.

Morita, R.Y.(1975). Psychrophilic Bacteria. Bacteriol Rev 39: 144-167.

Morozova, D., Möhlmann, D. and D. Wagner. 2006. Survival of methanogenic archaea from Siberian permafrost under simulated Martian thermal conditions. Origins of Life and Evolution of Biospheres, 37: 189-200.

Mountfort, D. O., Rainey, F. A., Burghardt, J., Kaspar, H. F. and E.Stackebrandt, 1998. Psychromonas antarcticus gen. nov., sp. nov., a new aerotolerant anaerobic, halophilic psychrophile isolated from pond sediment of the McMurdo Ice Shelf, Antarctica. Arch Microbiol 169: 231-238.

Mountfort, D. O., Rainey, F. A., Burghardt, J., Kaspar, H. F., and Erko Stackebrandt. 1997. Clostridium vincentii sp. nov., a new obligately anaerobic, saccharolytic, psychrophilic bacterium isolated from low-salinity pond sediment of the McMurdo Ice Shelf, Antarctica. Arch Microbiol 167: 54-60.

Nadeau, T.-L. and R. W. Castenholz. 2000. Characterization of Psychrophilic Oscillatorians (Cyanobacteria) from Abtarctic Meltwater Ponds. J Phycol 36: 914-923.

Narro, M. L., Cerniglia, C. E., Van Baalen, C. and D. T. Gibson. 1992. Metabolism of Pnenanthrene by the Marine Cyanobacterium Agmenellum quadruplicatum PR-6. Appl Environ Biol 58: 13511359.

Nozhevnikova, A. N., Simankova, M. V., Parshina, S. N. and O.R. Kotsyurbenko. 2001. Temperature characteristics of methanogenic archaea and acetogenic bacteria isolated from cold environments. Water Science \& Technology 44: 41-48.

Nozhevnikova, A. N., Zepp, K., Vazquez, F., Zehnder, A. J. B. and C. Holliger. 2003. Evidence for the Existence of Psychrophilic Methanogenic Communities in Anoxic Sediments of Deep Lakes. Appl Environ Microbiol 69: 1832-1835.

Okamoto, T., Fujioka, K. and T. Naganuma, 2001. Phylogenetic similarity of aerobic gram-negative halophilic bacteria from a deep-sea hydrothermal mound and Antarctic habitats. Polar Biosci 14: $1-9$. 
Paarup, M., Friedrich, M. W., Tindall, B. J. and K. Finster. 2005. Characterization of the psychrotolerant acetogen strain SyrA5 and the emended description of the species Acetobacterium carbinolicum. Antonie van Leeuvenhoek 89: 55-69.

Paniker, G., Aislabie, J. and A. K. Bej, (2006). Analysis of aggregative behavior of Pseudomonas sp. 30-3 isolated from Antarctic Soil. Soil Biol and Biochem 38: 3152-3157.

Paniker, G., Aislabie, J., Saul, D. and A. K. Bej, (2002). Cold tolerance of Pseudomonas sp. 30-3 from oil-contaminated soil, Antarctica. Polar Biol. 25: 5-11.

Perreault, N. N., Greer, C. W., Andersen, D. T., Tille, S., Lacrampe-Couloume, G., Lollar, B. S., and L. G. Whyte. 2008. Heterotrophic and Autotrophic Microbial Populations in Cold Perennial Springs of the High Arctic. Appl. Environ. Microbiol. 74: 6898-6907.

Pikuta, E. V. and R. B. Hoover. 2004. Astrobiological significance of chemo-lithoautotrophic acidophiles. Proc. SPIE, 5163: 179-190.

Pikuta, E. V., Hoover, R. B. and J. Tang. 2007. "Microbial extremophiles at the limits of life", Critic Rev Microbiol 33: 183-209.

Pikuta, E. V., Hoover, R. B., Bej, A K., Marsic, D., Whitman, W. B., Krader, P. E. and J. Tang. (2006). "Trichococcus patagoniensis sp. nov., a facultative anaerobe that grows at $-5{ }^{\circ} \mathrm{C}$, isolated from penguin guano in Chilean Patagonia”, Int J Syst Evol Microbiol 56: 2055-2062.

Pikuta, E. V., Hoover, R. B., Marsic, D., Whitman, W. B., Lupa, B., Krader, P. E. and J. Tang. 2009. "Proteocatella sphenisci gen. nov., sp. nov., a novel psychrotolerant, spore-forming anaerobe isolated from Magellanic penguin guano in Patagonia, Chile”, Int J Syst Evol Microbiol 59: - in press.

Pikuta, E. V., Marsic, D., Bej, A. K., Tang, J., Krader, P., and R. B. Hoover. 2005. Carnobacterium pleistocenium sp. nov., a novel psychrotolerant, facultative anaerobe isolated from permafrost of the Fox Tunnel in Alaska. Int J Syst Evol Microbiol 55: 473-479.

Price, R. B. 2000. A habitat for psychrophiles in deep Antarctic ice. PNAS, 37: 1247-1251.

Ryan, G., Priscu, J. Takacs-Veshbach, C. 2007. Extremophilic Bacteria from Antarctic Lake Fryxell:

Evidence for Phenotypic Convergence. http://mcmdvlakesmo.montana.edu/images/Data/posters/ASLO_RYAN_poster.pdf

Reddy, G. S. N., Prakash, J. S. S., Srinivas, R., Matsumoto, G. I. and S. Shivaji. 2003. Leifsonia rubra sp. nov. and Leifsonia aurea sp. nov., psychrophiles from a pond in Antarctica. Int J Syst Evol Microbiol 53: 977-984.

Reinsch, P. F. 1890. Die Süsswasseralgenflora von Süd-Georgien. In G. Neumeyer: Die Deutschen Expeditionen und ihre Ergebnisse 1882-01883. pp. 329-365.

Roberts, N. J., Burton, H. R., and Pitson, G. A. 1993. Volatile organic compounds from Organic Lake, an Antarctic hypersaline, meromictic lake. Antarctic Science 5: 361-366. 
Romanenko, L. A., Schumann, P., Rohde, M., Lysenko, A. M., Mikhailov, V. and E. Stackebrandt. 2002. Psychrobacter submarinus sp. nov. and Psychrobacter marincola sp. nov., psychrophilic halophiles from marine environments. Int J Syst Evol Microbiol 52: 1291-1297.

Sattley, W. M. and M. T. Madigan. 2007. Cold-active acetogenic bacteria from surficial sediments of perennially ice-covered Lake Fryxell, Antarctica. FEMS Microbiol Lett 272: 48-54.

Seckbach, J. and A. Oren. 2007. Oxygenic photosynthetic microorganisms in extreme environments: Possibilities and limitations. In: Algae and cyanobacteria in extreme environments (Ed. By J. Seckbach). Springer, pp. 5-25.

Sellman, P. V. 1967. Geology of the USA CRREL Permafrost Tunnel, Fairbanks, Alaska. U. S. Army CRREL Technical Report 199, pp 1-22. Hanover, NH

Shmidt, M., Priemé, A. and P. Stougaard, P. 2006. Rhodonellum psychrophillum gen. nov., sp. nov., a novel psychrophilic and alkaliphilic bacterium of the phylum Bacteroidetes isolated from Greenland. Int J Syst Evol Microbiol 56: 2887-2892.

Shmidt, M., Priemé, A., and P. Stougaard. 2006. Bacterial diversity in permanently cold and alkaline ikaite columns from Greenland. Extremophiles 10: 551-562.

Shmidt, M., Priemé, A., and P. Stougaard. 2007. Arsukibacterium ikkense gen. nov., sp. nov., a novel alkaliphilic, enzyme-producing $\gamma$-Proteobacterium isolated from a cold and alkaline environment in Greenland. Syst Appl Microbiol 30: 197-201.

Siegert, M. J., Ellis-Evans, J. C., Tranter, M., Mayer, C., Petit J., Salamatin, A. and J. C. Priscu. 2001. Physical, chemical, and biological processes in Lake Vostok and other Antarctic subglacial lakes. Nature 414: 603-609

Simankova, M. V., Kotsyurbenko, O. R., Stackebrandt, E., Kostrikina, N. A., Lysenko, A. M., Osipov, G. A. and A. N. Nozhevnikova. 2000. Acetobacterium tundrae sp. nov., a new psychrophilic acetogenic bacterium from tundra soil. Arch Microbiol 174: 440-447.

Simankova, M. V., Parshina, S. N., Tourova, T. P., Kolganova, T. V., Zehnder, A. J. B. and A. N. Nozhevnikova. 2004. Methanosarcina lacustris sp. nov., a New Psychrotolerant Methanogenic Archaeon from Anoxic Lake Sediments. Syst Appl Microbiol 24: 362-367.

Singh, N., Kendall, M. M., Liu, Y. and D. R. Boone. 2005. Isolation and characterization of methylotrophic methanogens from anoxic marine sediments in Skan Bay, Alaska, description of Methanococcoides alaskense sp. nov., and emendation of Methanosarcina baltica. Intl J Syst Evol Microbiol 55: 2531-2538.

Singh, S. M. and Elster, J. 2007. Cyanobacteria in Antarctic Lake Environments. In Algae and Cyanobacteria in Extreme Environments (J. Seckbach, Ed.), Springer, pp. 305-320.

Smol, J. P. and M. S. V. Douglas, 1996. Long term environmental monitoring in Arctic Lakes and ponds using diatoms and other biological indicators. Geoscience Canada, 23, 225-230. 
Spaulding S. A. and McKnight D. M. 1999. Diatoms as indicators of environmental change in Antarctic freshwaters. In E. F. Stoermer and J. P. Smol, Eds. The Diatoms: Applications for the Environmental and Earth Sciences. Cambridge University Press, pp. 345-363.

Staley, J. T., and J. J. Gosink. 1999. Poles apart: biodiversity and biogeography of sea ice bacteria. Ann Rev Microbiol 53: 189-215.

Straka, R. P. and J. L. Stokes 1960. Psychrophilic Bacteria from Antarctica. J. Bacteriol. 80: 622-625.

Taton, A., Grubisic, S., Brambilla, E., De Wit, R. and A. Wilmotte. 2003. Cyanobacterial diversity in natural and artificial microbial mats of Lake Fryxell (McMurdo Dry Valleys, Antarctica): a morphological and molecular approach. Appl Environ Microbiol 69: 5157-5159.

Trotsenko, Y. A. and V. N. Khmelenina. 2005. Aerobic methanotrophic bacteria of cold ecosystems. FEMS Microbiol Eco. 53: 15-26.

Van Heurck, H. 1909. Diatomées. In Expédition Antarctic Belge, Résultats du Voyage du S. Y. Belgica en 1897-1899. Botanique, 6: 1-126. Antwerp: Buschmamn.

Vincent, W. F. 2000. Cyanobacterial dominance in the polar regions. In: B.A. Whitton, and M. Potts (eds.) Ecology of Cyanobacteria: Their Diversity in Time and Space.Kluwer Academic Publishers, Dordrecht, pp. 321-340.

Voytek, M. A., Ward, B. B. and J. C. Priscu. 1998. The abundance of ammonia-oxidizing bacteria in Lake Bonney, Antarctica determined by immunofluorescence, PCR and in situ hybridization. Antarctic Research Series. The McMurdo Dry Valleys, pp. 217-228.

Wand, U., Schwarz, G., Bruggemann, E. and K. Brauer. 1997. Evidence for physical and chemical stratification in Lake Untersee (central Dronning Maud Land, East Antarctica). Antarctic Sci. 9: 43-45.

Wand, U. and J. Perlt. (1999). Glacial boulders "floating" on the ice cover of Lake Untersee, East Antarctica. Antarctic Science, 11: 256-260.

Wand, U., Samarkin, V.A., Nitzsche, H-M, and H-W. Hubberten. 2006. Biogeochemistry of methane in the permanently ice-covered Lake Untersee, central Dronning Maud Land, East Antarctica. Limnol Oceanogr 51: 1180-1194.

Ward, B. B. and J.C. Priscu. 1997. Detection and characterization of denitrifying bacteria in an icecovered Antarctic Lake. Hydrobiologia, 347: 57-68.

Ward, B. B., Granger, J., Maldonado, M. T., Casciotti, K. L., Harris, S. and M. L. Wells. 2005. Denitrification in the hypolimnion of permanently ice-covered Lake Bonney, Antarctica. Aquatic Microbial Ecology, 52: 197-205.

Ward, B. B., J. Granger, M. T. Maldonado and M. L. Wells. What limits bacterial production in the suboxic region of permanently ice-covered Lake Bonney, Antarctica. Aquatic Microbial Ecology, 31: 33-47 (2003). 
Wynn-Williams, D, W. 1990. Ecological Aspects of Antarctic Microbiology. Adv. Microbial Ecol. 11: 71-146.

Yang, S., Wu, R. S., and R. Y. C. Kong. 2002. Biodegradation and enzymatic responses in the marine diatom Skeletonema costatum upon exposure to 2,4-dichlorophenol. Aquatic Toxicology, 59: 191-200.

Zhang, G., Jiang, N., Liu, X. and X. Dong. 2008. Methanogenesis from methanol at low temperatures by a novel psychrophilic methanogen "Methanolobus psychrophilus" sp. nov., prevalent in Zoige wetland of the Tibetan Plateau. Appl Environ Microbiol 74: 6114-6120.

\section{Acknowledgements}

We want to thank James Pritzker and the Tawani Foundation, Valerii Lukin and the Arctic and Antarctic Research Institute/Russian Antarctic Expedition (AARI/RAE), Mirella Kruger of Antarctic Logistics Centre International (ALCI), Marty Kress and the Von Braun Center for Science and Innovation, NASA, NSF and the entire scientific and logistics team from Russia, Austria and the United States that worked tirelessly to make possible the 2008 International Schirmacher Oasis/Lake Untersee, Antarctica Expeditions. We also want to acknowledge the contributions to this study of Prof. Gopi Padilla of the University of Alabama in Huntsville and Melissa Guisler and Alissa Townsend. 